\title{
La filosofía como terapéutica vital humana II. ${ }^{\circ}$ La filosofía como medicina del alma y cura de almas
}

\author{
Domingo Natal Álvarez*
}

RESUMEN: "Esta convicción de que sabiduría y vida son indisociables hacía de la filosofía el saber terapéutico por excelencia. El término 'terapia' alude aquí a su función liberadora y sanadora: era 'remedio' para las dolencias del alma"1. Como dice Cicerón: La filosofía es "medicina del alma” (Tusculanas III, 3,6).

PALABRAS CLAVE: Saber, terapia, medicina del alma, sanar, remedio de las dolencias, cura de almas.

ABSTRACT: By this conviction that wisdom and life are inseparable, philosophy became therapeutic knowledge by excellence. The term 'therapy' refers here to the liberating and healing function: it was 'cure' for ailments of the soul. Philosophy is "medicine of the soul" (Tusc. III, 3,6). Cf. Estudio Agustiniano 44(2009)235-275.

KEYWORDS: knowledge, therapy, medicine of the soul, healing, remedies for diseases, cure of souls. (Para J.R., Flecha que nos enseñó la Moral cristiana del amor, la esperanza y la cura de almas).

\section{La cercanía de Epicteto a ciertas ideas "cristianas"}

Lo primero que ha impresionado mucho a Epicteto, como nos dicen las disertaciones de Arriano, es la cercanía del hombre a la divinidad y sus gra-

\footnotetext{
* E-mail: dnatak43@gmail.com

${ }^{1}$ M. Cavallé, La sabiduría recobrada. Filosofía como terapia, Barcelona 2006,14.
} 
ves consecuencias: "Si uno pudiera captar con justeza este pensamiento, el de que todos, en última instancia, procedemos de la divinidad y que la divinidad es el padre de los dioses y los hombres, creo que nadie tendría ningún pensamiento innoble o miserable sobre sí mismo"2.

En efecto: Sólo los seres racionales "por naturaleza participan de la relación con la divinidad ligados a ella por la razón": E I, 9,5. (De esto habla Catón y la carta $2^{\mathrm{a}}$ Pedro 1,4$)$. Ahora bien, no se puede ir a esa divinidad o suicidarse sin su señal ni abandonar, sin más, el género de vida a que nos ha destinado.

Por lo demás, el hombre muestra gran curiosidad por todo lo que hay en el mundo, pero se olvida de sí mismo, que es lo más importante: “Sí que viajáis hasta Olimpia para ver la obra de Fidias, y cada uno de vosotros considera una desdicha morir sin haberla visto! Y a donde ni siquiera hay que viajar, sino que ya estáis allí y tenéis ante vosotros las obras, ¿no deseáis contemplarlas y comprenderlas? ¿No os daréis cuenta ni de quiénes sois, ni de para qué habéis nacido, ni de cuál es el fin para el que recibisteis la vista?": E I, 6,23-25. Agustín dice: "Viajan los hombres a admirar las alturas de los montes, y las ingentes olas del mar", (...), "y se olvidan de sí mismos" (Conf. X, 8,15).

Dios nos da cuanto necesitamos para ser hombres auténticos, pero nosotros lo olvidamos: “¡Ea, pues! Date cuenta tú también y fíjate en las facultades que tienes y, al verlas exclama: envía, Zeus, la circunstancia que quieras, pues tengo los recursos que tú me diste y los medios para señalarme por miedo de los acontecimientos". Pues no, sino que seguís sentados, temiendo no sea que ocurran ciertas cosas, y lamentándoos y gimiendo y angustiándoos porque ocurren otras. Y después, os quejáis de los dioses. ¿Qué otra cosa puede seguirse de una tal bajeza sino la impiedad? "Y sin embargo, la divinidad no sólo nos concedió esas capacidades con las que podemos soportar todo lo que suceda sin vernos envilecidos o arruinados por ello, sino que además, como correspondía a un rey bueno y a un verdadero padre, nos las concedió incoercibles, libres de impedimentos, inesclavizables, las hizo absolutamente dependientes de nosotros, sin siquiera reservarse a sí mismo ninguna fuerza capaz de obstaculizarlas o ponerles impedimentos": E I, 6,37-41. Dice s. Agustín: "Da lo que mandas y manda lo que quieras"...

"Entonces, ¿por qué te agobias a ti mismo con aquello de lo que no eres responsable? Eso es buscarse uno problemas": E I, 12,35. Según el

\footnotetext{
2 Epicteto: Disertaciones por Arriano, Madrid 1993, Libro I, 3,1. En adelante E.
} 
Evangelio: "Basta a cada día su afán”. Pues para comer o vestir, los animales se arreglan, ¿el hombre no? Y también dice Epicteto: Entonces, hay que tener cuidado porque: “ ¿si te ves colocado en lugar eminente, al punto te constituirás a ti mismo en tirano?": E I1, 3,4. Para Agustín: hay que compadecerse del Prior porque "cuanto más elevado es el lugar que uno ocupa, tanto mayor es el peligro en que se halla": Regla 7,4.

La divinidad contempla y ve todo como el sol ilumina todo: E I, 14,910. Dice Agustín: Hay un super-inspector que está dentro de nosotros mismos a quien nada se le oculta: Regla 4,5. Sigue Epicteto: Debemos cantar un himno a la divinidad por los bienes que nos ha dado, y valorar sus dones como la identidad humana más admirable que la cresta del gallo o la melena del león: E I, 16,12. "Cuando vayas a uno de los poderosos, recuerda que también otro (la divinidad) desde arriba mira lo que sucede y que tú has de agradar a éste más que a aquél": E I, 30,1. Y: "No tratéis de agradar con los vestidos sino con las costumbres": Regla 4,19.

Para Epicteto: "En donde esté la verdad, allí también la naturaleza. Y allí está la precaución, en donde la verdad, y allí la valentía, en donde la naturaleza": E I, I 2,14. Y, aconseja: "Distingue las cosas y ponlas por separado y di: 'Lo exterior no depende de mí, el albedrío depende de mí. ¿Dónde buscaré el bien y el mal? En lo interior, en mis cosas"”: E II, 5,5. S. Agustín dice: "Vuelve a ti mismo, porque en el interior del hombre habita la verdad".

"Porque, ¿qué es un hombre? Una parte de la ciudad, primero de la de los dioses y los hombres y, después de eso, de la que te sea más cercana, que es un pequeño remedo de la universal": E II, 5,26. La divinidad hizo los otros seres pero no es igual a esos seres. “Entonces, ¿qué? ¿No son también ellos obra de la divinidad'? Lo son, pero no son primordiales ni partes de la divinidad. Mientras que tú eres primordial, tú eres una chispa divina; tienes en ti mismo una parte de ella. Entonces, ¿por qué no reconoces tu parentesco? ¿Por qué no sabes de dónde procedes? ¿No quieres recordar cuando comes quién eres al comer y a quién alimentas? ¿al tener trato amoroso, quién eres al hacerlo? Cuando estás en compañía, cuando te entrenas, cuando charlas, ¿no sabes que alimentas a la divinidad, que entrenas a la divinidad? Llevas a la divinidad contigo de un lado a otro, desdichado, y no lo sabes. ¿Te parece que hablo de algo que por fuera es de plata o de oro? Lo llevas en ti mismo y no te das cuenta de que está salpicándolo con pensamientos impuros, con acciones sucias": E II,8,10-14. La carta $2^{\text {a }}$ Petri 1,4, dice que somos: "Consortes divinae naturae", S. Pablo: "templos del Espíritu Santo", aunque "llevamos este tesoro en vasijas de barro"...

El que no se porta adecuadamente: "Ese no reconoce a la divinidad que hay en él, no sabe con quién va": E II ,8,16. Cada uno es su propio guar- 
dián según la encomienda de la divinidad. Y debe ser respetuoso, noble, divino en la enfermedad y en la muerte. Sócrates siempre rechazaba la injuria y el insulto. Este talante fue alabado por los clásicos. Dice Hesíodo: "al punto sabiamente ponía fin incluso a una gran disputa”: Teogonía 87. Dice Agustín: "No tengáis disputas o terminadlas cuanto antes": Regla 6,1.

Según los filósofos la divinidad existe y: "el que quiera agradarle y obedecerla intente, en la medida de lo posible, asemejarse a ella tal cual la halle. Si la divinidad es leal, también él ha de ser leal; si libre, también libre; si bienhechora, también el bienhechor; si magnánima, también él magnánimo; en resumen, hacer y decir todo lo demás como partidario de la divinidad": E II, 14,12. Para Agustín, Cristo es justicia, libertad y todo bien: In Jn 26,4.

"Extiende una vez el cuello como liberado de la esclavitud; atrévete, levantando la mirada hacia la divinidad, a decir: 'Úsame de ahora en adelante, como quieras; estoy unido a ti, soy tuyo, no me aparto en nada de lo que quieras, llévame adonde quieras, ponme el vestido que quieras. ¿Quieres que tenga cargos públicos, que lleve vida de particular, que me quede aquí, que sufra el destierro, que sea pobre, que sea rico; yo te defenderé por todo ello ante los hombres; mostraré cómo es la naturaleza de cada cosa"': E II,16,41-42.

El hombre puede luchar contra sus males aunque sólo Dios puede vencer la injusticia. Pero: "la tristeza, el miedo, el deseo, la envidia, la malevolencia, la avaricia, la molicie, la intemperancia. Eso no hay quien pueda expulsarlo más que mirando sólo a la divinidad, sintiendo afecto sólo por ella, consagrado a sus mandatos": E II,16,45. Cf. S. Agustín, De Agone Christiano, 11,12. Sólo hay que querer lo que la divinidad quiere: "Dadme un joven que haya venido a la escuela con este proyecto, que se haya hecho experto en esta materia y que diga: 'Por mí, que se vaya a paseo todo lo demás; me conformo con que alguna vez me sea posible pasar la vida sin impedimentos ni penas, alzar la cabeza ante los asuntos como hombre libre y alzar la mirada al cielo como amigo de la divinidad, sin temor a lo que pueda suceder"': E II,17,29.

Vencer la tentación de la seducción es más importante que hacer buenos silogismos: "Pero si aunque la mujercita esté dispuesta y me haga señas y me mande mensajes, si aunque me toque y se me acerque mucho me contengo y venzo este sofisma está ya por encima del Mentiroso” (...) “¿Cómo llegará a suceder esto? Estate dispuesto a agradarte alguna vez a ti mismo, estáte dispuesto a parecer honesto ante la divinidad. Desea llegar a ser puro con lo puro que hay en ti y con la divinidad": E II, 18,18-19. Cf. Regla 4,23: "Tema, pues, el religioso desagradar a Aquél, para no agradar vanamente a la mujer". 
"Es que ahora yo soy vuestro educador y vosotros ahora os educáis conmigo. Y yo tengo este proyecto: haceros libres de trabas, incoercibles, sin impedimento, libres, venturosos, felices, con la vista puesta en la divinidad para todo, (en) lo pequeño como lo grande; y vosotros estáis aquí para aprender y ejercitarlos en ello": E II,19,29. Pero cada uno busca su conveniencia y por ella se enfrenta hasta con los dioses: E II, 2,16.

"Haz que me entren ganas. Como cuando se le muestra a una oveja la hierba correspondiente le entran ganas de comer, pero si le pones al lado una piedra o pan no se mueve, así también hay en nosotros deseos naturales de hablar, cuando el que ha de escuchar parece alguien, cuando él mismo nos estimula": E II,24,16. S. Agustín: Se le muestra a una oveja el ramo verde y le atraes: in Jn 26, 4. El que no sabe quién es, ni qué es lo bueno y honesto, "irá de un lado a otro sordo y ciego pareciendo ser alguien, pero sin ser nadie": E II,24,19. Para S. Agustín: Nadie está más lejos de sí, que el que huye de sí mismo...

La belleza no está en la cosmética y adorno exterior, ni en el cabello sino en la libertad, por eso dice Sócrates a Alcibíades: "Adorna tu albedrío, arranca las opiniones viles": E III, 1,43. El hombre bueno y honrado ha de ejercitarse en tres temas: "el relativo a los deseos y los rechazos, para que ni se vea frustrado en sus deseos ni vaya a caer en lo que aborrece; el relativo a los impulsos y repulsiones y, sencillamente, al deber para que actúe en orden, con buen sentido, sin descuido; el tercero es el relativo a la infalibilidad y a la prudencia y, en general, el relativo a los asentimientos": E III, 2,1-2.

"Pero, ¿qué dice Sócrates?: 'Igual que uno -dice- disfruta mejorando su campo, otro su caballo, así yo disfruto día a día al percibir que me hago mejor"': E III, 5,14.

"A ti te parece pequeño todo lo que tienes; a mí, todo lo mío grande. Tu ansia es insaciable; la mía está saciada. Eso le pasa a los niños que meten la mano en un cacharro de cuello estrecho par sacar higos con nueces: si se llenan la mano, no pueden sacarla y luego lloran. Suelta un poco y la sacarás. Y tú igual: ¡suelta el deseo; no desees mucho y lo obtendrás!”: E III, 9,22. Dios protege a todos y todas las relaciones: "Y para con el hermano: 'Pues todos son de Zeus Fraterno'. E igualmente en todas las relaciones hallaremos a Zeus velando por ellas": E III, 11,6. Regla 1,1: Os reunís en comunidad para vivir con una sola alma en Dios.

Algunos se creen desdichados, "pues no conciben una vida a solas y eso impulsados por un principio natural: el de que somos por naturaleza sociables y amantes de la compañía y con gusto tenemos trato con los hombres. Pero no ha de estar uno en absoluto menos preparado para poder bas- 
tarse a sí mismo, para poder uno convivir consigo mismo": E III, 13,5-6. Como Zeus vive consigo meditando, "así también seamos nosotros capaces de hablar con nosotros mismos, de no necesitar a otros, de no andar escasos de entretenimientos: examinar el gobierno divino, nuestra relación con los demás, observar cómo nos comportábamos antes frente a los acontecimientos y cómo ahora; cuáles son las cosas que aún nos atormentan, cómo podrían, también ellas, ser remediadas, cómo podrían ser extirpadas; y si alguna de estas cosas necesita perfeccionamiento, perfeccionarlas según su razón” E III,13,8.

"Igual que los malos actores trágicos son incapaces de cantar los solos y (...) han de cantarlos con el coro, así también hay algunos incapaces de andar solos. Hombre, si eres alguien, anda solo y habla contigo mismo y no te escondas entre el coro. Préstate a la broma alguna vez, mira en torno tuyo, sacúdete para que sepas quién eres": E III, 14,1-3. El hombre ha de ser coherente y no hacer teatro como un niño: "Has de ser un hombre o bueno o malo. Has de cultivar o tu propio regente o lo exterior. $\mathrm{O}$ poner tu esfuerzo en lo interior o en lo exterior. Es decir, o tener la disposición de un filósofo o la de un particular": E III, 15,13.

La vida es lucha, como el deportista el hombre bueno todo lo hace bueno: “¿Qué harás con la enfermedad?'. Mostraré su esencia, me luciré con ella, me mostraré equilibrado, sereno, no adularé al médico, no pediré a los dioses la muerte. ¿Qué más quieres? Todo lo que me des lo haré yo bienaventuranza, felicidad, venerabilidad, objeto de envidia": E III, 20,14-15.

El constructor se muestra en su obra: "Haz tú algo semejante: come como hombre, bebe como hombre, arréglate, cásate, ten hijos, ocupa cargos; abstente de insultar, soporta al hermano insensato, soporta al padre, al hijo, al vecino, al compañero de viaje. Muéstranos eso, para que veamos que en verdad has aprendido algo de los filósofos": E III, 21,5-6.

El cínico es enviado de Dios a los hombres para enseñarles el bien y el mal, pues viven engañados: "Porque, en realidad, el cínico es espía de qué es lo amigo y qué lo enemigo de los hombres": E III, 22,24. La felicidad no está en el cuerpo ni en las posesiones o el poder: E III 22, 27. Según s. Agustín, la Palabra de Dios es nuestro amigo y enemigo...

"- ¿Y dónde me hallarás un amigo del cínico? Pues es preciso que ése sea otro igual, para que sea digno de ser contado como amigo tuyo": E III 22,62. El cínico como mensajero y heraldo de la divinidad, no debe casarse pues se entrega a la comunidad, al pueblo y se ocupa de muchas cosas. "Pero en tal situación revuelta como la presente, como en orden de batalla, ¿no es preciso que esté el cínico libre de distracciones, todo él al servicio de la divinidad, capaz de frecuentar el trato de los hombres, no atado a 
deberes particulares ni implicado en relaciones, que al transgredirlas ya no pueda preservar su papel de bueno y honrado y, por el contrario, manteniéndolas, eche a perder la de mensajero y espía y heraldo de los dioses?": E III,22,69.

No se trata de una vana profesión cualquiera. Por el contrario: "Hombre, él ha engendrado a todo los seres humanos, tiene por hijos a los hombres; por hijas a las mujeres. Así se acerca a todos, así se ocupa de todos". “- Sí, pero Crates se casó”: E III, 22,81. S. Pablo dice: el que tiene mujer como si no la tuviera, que son tiempos difíciles.

“- Me hablas de una situación nacida del amor, y pones una mujer que era otro Crates. Pero nosotros buscamos en los matrimonios comunes y convencionales y buscando en ellos no hallamos en esta situación revuelta que sea asunto de interés para el cínico": E III, 22,76 (cf. 1 cor 7,25-35). El cínico, amigo de los dioses y a cuyo cargo están los pueblos, se le pide "ante todo, que sea su regente más limpio que el sol; si no, por fuerza actuará al azar y sin escrúpulos quien, atrapado él mismo en un vicio, reprenda a los demás": E III, 22,93.

"En primer lugar, dite a ti mismo quién quieres ser. Y, luego, de acuerdo con eso, haz lo que haces": E III, 23,1-2. Así hacen los atletas, los carpinteros, los herreros y demás. "La escuela del filósofo, señores, es un hospital: no habéis de salir contentos, sino dolientes; pues no vais sanos, sino el uno con luxación de hombro; otro, con un absceso; otro, con una fístula; otro con dolor de cabeza": E III, 23,30. Se trata de mejorar:"-¿No sabes que un hombre bueno y honrado no hace nada para parecer, sino para que esté bien hecho? (...) Buscas para el hombre bueno una recompensa mayor que la de hacer lo bueno y justo? (...) ¿Te parece que es tan poca cosa y de tan poca monta el ser honrado y bueno y feliz?": E III,24,50-52.

La vida es cambio y este mundo "una ciudad'. "Todo está lleno de seres queridos: en primer lugar de dioses, y luego también de hombres íntimamente unidos unos a otros por naturaleza; y es preciso que unos se acerquen mutuamente y que otros se ausenten, deleitándose con aquellos con quienes conviven pero sin sufrir por los ausentes": E III, 24,11: Confs. IV, 8,13.

"La vida de cada uno es una campaña, y larga y variada. Tú has de mantener la actitud del soldado y hacerlo toda a una seña del estratega. Y si fuera posible, adivinando lo que quiere": E III, 24,34. No hay pretextos para no hacer el bien, pues Sócrates también quería a sus hijos: "Pero los quería como libre, como quien recuerda que, en primer lugar, hay que ser amigo de la divinidad. Por eso no transgredió nada de lo que convenía a un hombre bueno ni al defenderse ni al proponer su propia pena ni tampoco antes, al participar en el consejo o en la campaña": E III, 24,61. 
Por eso, no conviene ser desdichado por nadie "sino ser dichoso gracias a todos, y especialmente gracias a la divinidad que para eso nos dispuso”. Diógenes, “¿cómo amaba? Como correspondía a un ministro de la divinidad, al mismo tiempo tomándose interés y sometido a ella. Por eso, sólo para él era su patria cualquier tierra, pero ninguna en especial": E III, 24,65-66.

"Aquel a quien no supera el placer ni el trabajo ni la gloria ni la riqueza y que puede, cuando le parezca, escupirle a alguien todo su cuerpecillo y marcharse, ¿de quién va a seguir siendo esclavo, a quién estará subordinado?": E III,24,71.

A toda felicidad supera 'la de comprender que obedeces a la divinidad' y vivir como un hombre honrado y bueno 'destinado a la divinidad y a sus mandatos y órdenes'. Ella misma nos atestigua: "Ved que teméis sin razón, que en vano deseáis lo que deseáis. No busquéis el bien afuera, buscadlo en vosotros mismos. Si no, no lo hallaréis": E III, 24, 112-114. S. Agustín dice: "No te vayas afuera sino vuélvete a ti mismo"...

"Nos hablas como si hubieras salido impune, como si uno le contestara al médico cuando le prohíbe bañarse: ‘¿Es que no me bañé hace poco?' Si el médico pudiera responderle diría: 'Ea ¿y qué te pasó al bañarte? ¿No te dio fiebre? ¿No tuviste dolor de cabeza?"”: E III, 25,7. Regla 5,34: "No se niegue el baño al cuerpo... pero hágase lo que dice el médico".

Para Epicteto es una vida de enfermos el ser servido por otros: "Eso te aterra, el no poder hacer vida de enfermo; así que aprende la de los sanos, cómo viven los esclavos, cómo los obreros, cómo los genuinos filósofos, cómo vivió Sócrates -y ése, con su mujer e hijos-, cómo Diógenes, cómo Cleantes, asistiendo a la escuela y aguador al tiempo": E III,26,23. S. Agustín dice en la Regla 3,18: Ni quieran seguir enfermos cuando ya están sanos.

No hay que reclamar más que la libertad y el bien: "Pues soy libre y amigo de la divinidad para hacerle caso voluntariamente": E IV,3,9-10. No hay que indisponerse por las cosas que pasan sino: "sencillamente, acuérdate de que si estimas cualquier cosa fuera de tu propio albedrío, has echado a perder el albedrío": E IV, 4,23.

"El hombre bueno y honrado ni disputa él mismo con nadie ni, en la medida de sus fuerzas, se lo permite a otros": E IV, 5,1-2. "Y esta es la naturaleza de todos los seres: perseguir el bien, rehuir el mal" (...) "Pues nada nos es tan próximo como el bien. Así que si ésos son los bienes y los males, no hay padre querido para sus hijos, ni hermano para su hermano, sino que todo está por todas partes lleno de enemigos, de intrigantes, de delatores": E IV,5,30-31. 
"Sólo te ha sido dado el convencerte a ti mismo. Y aún no te has convencido. Así que ¿cómo me intentas ahora convencer a los demás? ¿Y quién pasa contigo tanto tiempo como tú mismo? ¿Quién es tan persuasivo contigo para convencerte como tú mismo? ... ¿No quieres, entonces, dejando a los demás, ser para ti mismo discípulo y maestro? ": E IV, 6,6-8.

"Yo he meditado sobre todas las cosas; sobre mí nadie tiene potestad. He sido liberado por la divinidad, conozco sus mandamientos, ya nadie podrá esclavizarme, tengo un emancipador como es debido, unos jueces como es debido": E IV, 7,16-7. "Considero que es mejor lo que quiere la divinidad que lo que quiero yo. Me entregaré a ella como servidor y acólito, tendré sus mismos impulsos, sus mismos deseos; en suma, querré lo mismo": E IV,20. "Sed imitadores de Dios como hijos queridos": Efesios 5,1.

No debemos pelearnos por los cargos ni por bienes secundarios como los niños. El filósofo no lo es:-"Porque lleva un manto raído y melena" (E IV, 8,5), sino porque hace las cosas no para los espectadores sino por sí mismo: "Todo por mí mismo y por la divinidad": E IV, 8,18. "Mira cómo como, cómo bebo, cómo duermo, cómo aguanto, cómo me contengo, cómo me abstengo, cómo colaboro, cómo uso del deseo y del rechazo, cómo mantengo las relaciones naturales o adquiridas sin confusiones ni trabas. Júzgame en eso si puedes": E IV, 8,20.

"Yo he sido enviado por la divinidad como ejemplo no ya sin hacienda ni casa ni mujer ni hijos, sino incluso sin lecho ni ropa ni ajuar. Y ved qué sano estoy": E IV, 8,31. Según el Evangelio: "El hijo del hombre no tiene donde reclinar su cabeza"... "Cuando veas a otro con un cargo, supón que tú tienes el no necesitar un cargo. Cuando veas a otro con riquezas mira qué tienes en lugar de eso. Pues si no tienes nada en su lugar, eres un desdichado. Y si tienes el no tener necesidad de riqueza, date cuenta de que tienes más y mucho más valioso": E IV, 9, 1-2. Lo importante es ser "un hombre bueno": "porque es mejor necesitar menos que tener más": Regla 3,18.

"Lucha contigo mismo, recupérate a ti mismo para la compostura, para el respeto, para la libertad": E IV, 9,11. "Ten un sentimiento semejante. Pues sabe que nada es más fácil de seducir que el alma humana. Es preciso que quiera y ya está hecho: se ha corregido. Como a la inversa: se adormila y está perdida. Pues la perdición y la ayuda están en su interior": E IV, 9,16. Así, cuando dijiste basta, empezó tu perdición: "Proba et te ipsum tu ipse. Semper tibi displiceat quod es, si vis pervenire ad id quod nondum es. Nam ubi tibi placuisti, ibi remansisti. Si autem dixeris: Sufficit; et peristi": Sermón 169,18. Del mismo modo exhorta Agustín: "Eia, fratres, redite ad vos, inspicite vos, interrogate vos, vera respondete vobis, et iudicate vos non secumdum personam, sed iustum iudicium iudicate"(...) "Christianus es, fre- 
quentas ecclesiam, amas verbum Dei, et libenter audis. Ecce hoc quod propono, in eo te examina, in eo te appende, in eo ascende mentis tuae tribunal, et constitue te ante te, et iudica te: et si pravum inveneris, corrige te": Sermón 178,7 .

“¿Qué quieres estar haciendo cuando te halle la muerte? Yo, mi parte: alguna obra humana, benéfica, útil para la comunidad, noble": E IV, 10,12.

No hay que dejar las cosas para mañana: pues "si mañana va a estar bien, ¡cuánto mejor hoy! Si mañana va a ser conveniente, mucho más hoy, para que también mañana seas capaz y no lo retrases de nuevo a pasado mañana": E IV, 12,21. Conf., san Agustín: “Cras, cras"...

"Cuando nos parece que alguien charla con sencillez sobre sus propios asuntos, alguna vez, de algún modo, nos vemos llevados también nosotros a darle a conocer nuestros secretos, y eso creemos que es sinceridad": E IV,13,1-2."Pero muéstrateme leal, con decoro, firme; muéstrame que tienes opiniones amistosas, muestra que tu tinaja no está agujereada y verás cómo no espero a que me confíes lo tuyo, sino que yo mismo voy y te pido que escuches lo mío": E IV,13,15. Pues, compartir alivia la dificultades, "como si fueran una carga", y aumenta la confianza. S. Pablo dice: "Llevad unos las cargas de los otros y así cumpliréis la ley de Cristo".

Según Simplicio, es filósofo el hombre que por medio de las virtudes catárticas huye de las pasiones irracionales, se concentra en sí mismo y su alma: "Le fait de vouloir se tourner exclusivement vers soi-même, donc vers son âme raisonnable, de vouloir réaliser cette 'conversión', est reconnu plus loin par Simplicius comme la marque de quelqu'un qui est désormais désireux de pratiquer la philosophie, et c'est à ce genre d'hommes que s'addresse, selon Simplicius, la deuxième parti du Manuel (à partir du ch. 22)"3. Así, se conseguirá la iniciación a una formación filosófica y moral.

No se trata sólo de aprender cosas sino "et surtout pour se transformer soi-même ainsi que le lecteur": SM 55. Como dice Simplicio, se trata de que estando enfermo y habiendo encontrado en los escritos el remedio a la enfermedad no se lean en vano, sin usar esos remedios. Así, la filosofía antigua difiere de la moderna porque: "l'une étant une manière de vivre, l'autre un discours et une construcción des systèmes", como muestra Hadot en: Ejercicios espirituales y la filosofía antigua: SM 55.

Esos ejercicios espirituales son prácticas de meditación, examen, oración, etc. Eso es lo que hace Simplicio al comentar el Manual de Epicteto.

\footnotetext{
${ }^{3}$ Simplicius, Commentaire sur le Manuel d'Epictète. Introduction \& édition critique du texte grec Ilsetraut Hadot. Leiden 1996, 53. En adelante SM.
} 
Más en concreto, utiliza también la plegaria: "je te supplie, seigneur, père et guide de la raison qui est en nous, de nous faire ressouvenir de la noblesse originelle que nous avon reçu de toi et de nous prêter assistance, à nous, en tant qu'êtres mus par eux-mêmes, afin de que nous puissions nous purifier du corps et des passions irrationalles": SM 56. Así, podremos ver la luz de la verdad y superar las tinieblas de nuestros ojos, y, como dice Homero: "nous puissions bien connaître aussi bien Dieu que l'homme" (In Ench. Epict. E, 6-15)": SM 56.

El comentario de Simplicio al De coelo de Aristóteles, se cierra también con una plegaria que es un himno al Creador y una súplica para adorarle trascendente a la creación: SM 57. Así, la actitud del exegeta de Platón o Aristóteles es parecida a la del exegeta cristiano de las Escrituras que es un ejercicio de piedad para acercar a todos la verdad de la fe como dice y hace san Agustín: SM 58.

Simplicio y sus compañeros habían discutido mucho sobre la virtud, el pecado y el alma, y si aquella es la vida del alma y este la muerte o si la cambian sustancialmente: SM 83. Jambílico, Plotino y Porfirio, y los Platonici libri se han preguntado por el origen y la vida del alma humana. S. Agustín en Contra Secundinum 15, dice que el mal y la falta de virtud disminuye el alma humana y la razón: "Or moins elle est, plus elle est proche du néant. Car tout ce dont lêtre diminue tend au néant absolu. Et quoique l'âme ne parvienne pas à n être plus rien en mourant tout à fait, il est néamoins evident que n'importe laquelle de ses défaillances est le début de la mort": SM 103.

Para los neoplatónicos, al dejar de ser buena, el alma pierde su verdadero ser y camina hacia la nada: SM 103, y, para S. Agustín, cuando el alma se aparta de la razón, va perdiendo su ser y su esencia (defectum ab essentia) y tiende hacia la nada y la muerte. Con todo, estando de acuerdo en eso, "cependant nous nions le conséquent, à savoir que ce qui tend vers le néant meurt, c'est-à-dire atteint le néant" (De inmort. animae VII,12): SM 104. Todo su ser le viene de Dios que lo conserva en su interior pero va siempre a menos cuando se pierde en las cosas: De musica VI, 13,40.

La filosofía tiende a perfeccionar las virtudes y la razón. Así el $M a$ nual, según Simplicio, se dirige a los que comienzan su formación moral ( $\mathrm{I}^{\mathrm{a}}$ parte), a los que comienzan los estudios de filosofía (II ${ }^{a}$ parte) (SM 146-7). Y, según Pohlenz e I. Hadot, tiene 3 temas fundamentales:

$1^{\circ}$.- sobre el deseo y su dominio para liberarse de las pasiones,

$2^{\circ}$.- sobre la tendencia positiva y el cumplimiento de los deberes y

$3^{\circ}$.-sobre el asentimiento y la lógica del juicio, que lleva a la verdad pura: SM 149-150. 
El comentario se termina, según la costumbre neoplatónica, con una oración, que sirve de recapitulación del contenido, y en la que se pide al Padre y Guía de la Razón que conceda la gracia de apropiarse las exhortaciones contenidas en el Manual y su comentario: SM 151.

Según Ilsetraut Hadot, Arriano, que escribió la vida de Epicteto y su muerte, compone el Manual con las propuestas de Epicteto que considera más apropiadas para la filosofía y más estimulantes para las almas, como dice en su carta a Masalenos, a quien dedica su obra, porque era un gran admirador de Epicteto: SM 152. Y, también trata de unas Entretiens de Epicteto que no han llegado a nosotros aunque se sabe que existieron. A veces, Simplicio, trasmite detalles de la vida de Epicteto tomados de otros autores pero los amplifica, por eso son muy poco o nada fiables, por ejemplo, cuando nos ofrece y trasmite noticias sobre la salud de Epicteto: SM 152, n.13.

\section{Las aportaciones de Séneca a nuestra cultura humana y religiosa}

Hoy día, los estudiosos consideran su correspondencia epistolar con S. Pablo como una pura leyenda. J. F. Nourrisson pensaba que Séneca era la principal fuente de Agustín sobre el estoicismo, a lo que se opuso frontalmente el gran gurú del estoicismo, Max Pohlenz. A pesar de las escasas evidencias de citas, los especialistas franceses insistían. Marrou piensa que Agustín conocía la obra de Séneca desde su época de estudiante. Bardy dice que conocía La consolación a Marcia y otras, y cita civdei. XIII, 10, como referencia, pero no parece claro ${ }^{4}$.

Ruth Allison ve paralelos entre los dos De beata vita. Otros, en cambio, descartan su influencia. Courcelle ve algunas semejanzas en sus estudios de las Confesiones. Marrou dice que, ambos autores tienen la misma idea de las artes liberales. Pero Hagendhal cree que Agustín muestra poco interés por el estoicismo romano excepto en el tema de la superstición ${ }^{5}$. Aquí, más que de influencias se podría hablar de aproximaciones a nivel de pensamiento.

\footnotetext{
${ }^{4}$ Cf. Séneca, Diálogos. Consolaciones a Marcia, a su madre Helvia y a Polibio, Madrid 1996, 66. No parece que haya ningún rastro en el texto de esa influencia en la Consolación a Marcia. Por citar alguno, valga este: "Para esto fuiste engendrado, para perder, para perecer, para tener esperanza y temores, inquietar a otros y a ti mismo, para tener miedo a la muerte y a la vez desearla y, lo peor de todo, no saber nunca en qué situación te hallas". Todo muy estoico y poco cristiano, aunque alguna persona muy "cristiana" haya dicho genialmente: "Venimos a este mundo a perderlo todo"...

${ }^{5}$ H. Hagendahl, Augustine and the latin Classics, Götenborg 1967, 678-680.
} 
V. Capanaga también encuentra ciertas aproximaciones entre ambos autores, o algo más, cuando dice: Por varios indicios, "puede advertirse la afinidad del pensamiento agustiniano con el de Séneca, sobre todo en el libro De beata vita". Tertuliano decía: Seneca saepe noster. Además, Séneca, como Mónica y Adeodato, piensa que: Animus nisi purus ac sanctus est, Deum non capit: CL 87. Pero, Agustín se halla mucho más orientado a Dios que Séneca que vive muy sumergido en sí mismo: De tuo gaude; teipso et tui optima parte: CL 23. Agustín piensa ser feliz en esta vida, pero luego ve que sólo lo será en el gozo del paraíso: "Pero la esencia de la vida subsiste siempre: et ipsa beata vita, dirá más tarde, gaudere ad te, de te, propter te: ipsa est et non altera. Quia autem aliam putant esse, aliud sectantur gaudium, neque ipsum verum": Conf X, 22, $32^{6}$.

Pero, el logos estoico: "No es un logos cristiano, aunque le es tan cercano que hay momentos en los que llega a identificarse con él hasta fundirse. No olvidemos que hay una insoslayable diferencia entre el logos cristiano y el estoico: aquél es personal, infinito y se hizo carne; éste es impersonal, y no llega hasta la carne, sino que se hace locuela, discurso, palabra, palabra poética" 7 . En todo caso, en Séneca permanece lo sagrado. Pues: "¿No fue Séneca un estoico? ¿Y no fue el estoicismo una planta semítica en tierras filosóficas? ¿No están en oriente las raíces de la mística ascética española" 8 . ¿Y no es suyo el famoso: "Memento te esse deum?".

Con todo dice Séneca: “¿Por qué nos dolemos de la Naturaleza? Ella se comporta bondadosamente: la vida, si sabes emplearla, es larga. Pero a uno le domina una avaricia insaciable; al otro, la constante ocupación en tareas inútiles; uno se entrega al vino, otro se aburre en la ociosidad"9.

Algunos se quejan de que no les escuchan los superiores: “¿Cómo se atreve a dolerse de la altivez de otro quien no tiene nunca un momento para sí mismo?": BV 2. Algunos, sacados del baño en brazos, e instalados en su silla preguntan: “¿YYa estoy sentado?’. ¿Crees tú que este que ignora si está sentado, sabrá si vive, si ve, si reposa?": BV 12. En Soliloquios, 1,1 Agustín pregunta: -“Tú que deseas conocerte, ¿sabes si existes?”...

${ }^{6}$ San Agustín, O. C. I. Escritos Filosóficos (1º), Madrid 1994,6ª Preparado por Victorino Capanaga, 538;586.

${ }^{7}$ L. Ferrero Carracedo, Razón Dramática y Pensamiento, Madrid 2008, 304-5.

${ }^{8}$ L. Ferrero Carracedo, Razón Dramática..., 307.

${ }^{9}$ Séneca, De la brevedad de la vida = BV y otros diálogos (De la Providencia = DP; De la vida feliz $=\mathrm{VF}$; De la tranquilidad del alma $=\mathrm{TA}$; De la constancia del sabio $=\mathrm{CS})$, Madrid 1984, BV 2. 
"Los únicos que disfrutan del ocio son los que se dedican a la sabiduría: sólo estos viven, pues, no sólo emplean bien el tiempo de su existencia, sino que le añaden todas las edades, ya que se aprovechan de todos los años que transcurrieron antes de ellos (...) Nosotros nos iniciamos en bellísimas verdades sacadas de las tinieblas a la luz por obra de otros" (...) "Podemos discutir con Sócrates, dudar con Carnéades, descansar con Epicuro, dominar con los estoicos la humana naturaleza, salirnos de ella con los cínicos": BV 14.

No dependió de nosotros nacer, "pero de nuestra voluntad depende el nacer a nosotros mismos": BV 15,50. Según el Evangelio: "Hay que nacer de nuevo"...

Nadie piensa, normalmente, en la muerte, pero "algunos disponen hasta de lo que hay más allá de la vida, ordenando sepulcros grandiosos, dedicaciones de edificios públicos, ofrendas fúnebres y magníficas exequias": BV 20. En Conf. 9,12-13, Agustín narra la cristiana muerte de Mónica...

"Entre los hombres virtuosos y los dioses existe una amistad cimentada en la misma virtud. ¿Amistad, digo? Mejor diría parentesco y semejanza, ya que sólo la duración de su vida distingue al hombre bueno de un dios, del cual es discípulo, imitador y verdadero hijo, educado con la dureza propia de un padre severo por aquel glorioso progenitor, vigoroso ejecutor de las virtudes": DP 1. Los escritos paulinos dicen: "Sed imitadores de Dios como hijos queridos"...: Ef., 5,1.

"La adversidad es ocasión de virtud" (...) "Así, pues, Dios prueba, ejercita y da fuerzas a aquellos a quienes ama": DP 4. Pues: "Dios al que ama castiga como hacen los padres”... ¿QQué tiene de extraño que Dios tiente duramente a los espíritus generosos?": DP 4. "He puesto todos los bienes en el interior; vuestra felicidad consiste en no echar de menos la felicidad": DP 6.

"Todos los hombres, hermano Galión, desean vivir felices, pero, para ver qué es lo que puede hacer feliz una vida, todos andan a ciegas": VF 1. "El hombre feliz es aquel para quien no existe más bien ni mal que un alma buena o mala; que rinde culto al bien y se contenta con la virtud": VF 4. No se deja abatir por la fortuna, vive en libertad, procura hacer el bien, y desprecia el placer. "Por todo esto puede afirmar rotundamente que el supremo bien es la armonía del alma, puesto que las virtudes deberán forzosamente encontrarse donde haya acuerdo y unidad; el desacuerdo es propio de los vicios": VF 8. "Así, pues, vivid todos en unidad de alma y corazón y honrad los unos en los otros a Dios, de quien os habéis convertido en templos": Regla 1,8.

La razón guía el alma a la virtud y el placer a la esclavitud. "Hemos nacido en un reino: obedecer a Dios es libertad": VF 15. "La verdadera feli- 
cidad se encuentra, pues, en la virtud": VF 16. Nacimos para los demás y todo se nos ha dado: "Yo solo fui dado a todos, y todos a mí solo": VF 20. Las riquezas deben tener su lugar, sin esclavizarnos: "mis riquezas me pertenecen; tú perteneces a las tuyas": VF 22. "Mientras por todas partes me saludarán como a un dios, yo me creeré más que nunca un hombre": VF 25.

"Sin embargo - ¿por qué no confesarte, como a un médico, la verdad?": TA 1. S. Agustín dice a Dios: Yo soy el enfermo, tú el médico... "Creo que muchos hubieran podido llegar a la sabiduría, de no haber creído que ya la habían alcanzado”..."¿Quién se atreve a decirse a sí mismo la verdad?”:TA 1. Agustín dice: Sé valiente, enfréntate a ti mismo, porque "donde dijiste basta, te perdiste"...

"Y así se emprende un viaje tras otro y un espectáculo sigue a otro sin cesar. Como dice Lucrecio: "Así cada uno huye de sí mismo”: TA 2. Confes. 10,1-2. Pero, además: "Si te retiras a estudiar, evitarás el cansancio de la vida, y no ansiarás, hastiado del día, que llegue la noche; no serás ni una carga para ti mismo ni un estorbo para los demás; muchos se sentirán atraídos a tu amistad y los mejores se acercarán a ti. Porque la virtud, por oscura que sea, no permanece nunca oculta":TA 3. "Por lo demás, nada hay que deleite tanto el espíritu como una amistad fiel y dulce": TA 7.

Debemos amar la sobriedad sin la que ninguna riqueza basta, "pudiendo la misma pobreza, en virtud de la frugalidad, convertirse en riqueza": TA 9. "Una misma cárcel encierra a todos, y los que ataron a otros están atados igualmente (...) Toda la vida es una esclavitud": TA 10. "No envidiemos a los que están encumbrados; lo que parece altura es precipicio": TA 10. Para Agustín, la autoridad: "cuanto está en lugar más elevado tanto se halla en mayor peligro" (Regla 7,4).

"Otra causa, no desdeñable, de preocupación es el querer acicalarse con esmero y no mostrarse natural con nadie. Así es la vida de muchos: fingida y pronta sólo a la ostentación": TA 7; "ni procuréis agradar con el modo de vestir sino con la manera de comportaros": Regla 6,1. "Conviene concentrarse a menudo en sí mismo (...) Por ello, hay que mezclar y alternar estas dos cosas: la soledad y el trato": TA 17.

"El alma no puede alcanzar lo sublime ni lo arduo mientras permanezca vertida en sí misma; es necesario que se aparte de lo sólito, se eleve, y, masacrando sus frenos, se lleve consigo a quien la guía, hasta conducirle allí donde por sí misma no se hubiera atrevido a subir": TA17.

"Con todo, fue él quien se llevó la victoria, y en una tierra ocupada, se mostró no sólo invicto, sino indemne", (...) "la posesión de todo cuanto nos llega del exterior es escurridiza e incierta": CS 5. El tesoro del hombre bueno no corre peligro, como las murallas "que guardan al sabio no están 
expuestas a incendio ni asalto y no ofrecen brecha alguna, que son altas, inexpugnables, iguales a los dioses": CS 6. Nada puede perjudicar al amante de la sabiduría pues "el sabio está cercano a los dioses, semejante ellos, excepto en la inmortalidad": CS 8.

"Tampoco se envanecerá porque un gran número de hombres ricos le admiren, ya que sabe que en nada difieren de los mendigos, o mejor dicho sabe que son aún mas infelices, ya que éstos tienen pocas necesidades y ellos muchas": CS 13. Agustín envidia a un mendigo feliz: Conf. 6,6. Por lo demás: "Es interés de la república del género humano la existencia del hombre invencible, de aquel contra quien nada puede la fortuna": CS 19.

"Yo te digo que desde que naciste caminas hacia la muerte"10. Agustín dice que: No sabemos si esta es una vida mortal o una muerte vital. Así: Los animales huyen del peligro y se quedan tranquilos, pero "nosotros nos atormentamos por el futuro y el pasado”: CL5. “¿Me preguntas qué progresos he realizado? He comenzado a ser amigo de mí mismo'. Grande fue el progreso que hizo: nunca más se encontraría solo. Puedes estar cierto que este hombre es amigo de todos": CL6.

Hay que disipar los temores, la vida es breve, el tiempo huye: "La muerte sigue, la vida me huye": CL49. "Cada día morimos, cada día perdemos una porción de nuestra vida, y hasta cuando crecemos, nuestra vida decrece": CL24. "Quien no quiere morir no quiere vivir. Ya que la vida nos ha sido dada bajo la condición de la muerte y a la muerte nos conduce. Temerla es propio de un demente, porque las cosas ciertas se esperan, las dudosas se temen": CL30.

Según los epicúreos: "Quien siente menos necesidad de las riquezas es el que más goza de ellas": CL14. Regla 3,5:"porque es mejor necesitar menos que tener más". Conviene ejercitar el cuerpo; hay ejercicios breves y fáciles como la carrera, el salto, "sea aquel que podemos llamar 'salio (1)', o menos decorosamente, 'salto del fulón (2)'; adopta de cualquiera de esos ejercicios un uso simple y fácil”: CL15. "Nota 1. Llamado así de los salii o sacerdotes danzantes de Marte". "2. Los fullones eran esclavos que lavaban la ropa saltando encima del cubo de la colada": Ib. "El lavado de la ropa, realizadlo vosotros mismos sive a fullonibus" (Regla 5,4).

Por lo demás, pensemos...: "Ya que cuanto hacemos no es para ejercitar la voz, sino para ejercitarnos a nosotros mismos": CL15. Según la Regla 2, 3: "Cuando oréis a Dios con salmos e himnos, sienta vuestro corazón lo que presentáis con la voz".

${ }^{10}$ Séneca, Cartas morales a Lucilo. Barcelona 1984, 4. En adelante CL. 
"La vida del insensato es ingrata y llena de temores y lanzada hacia el porvenir": CL 15. "Ve mirando hombre por hombre, considérales en conjunto; no hay ninguno que no viva pensando en el mañana. Me preguntarás qué mal hay en ello. Incalculable, ya que estos no viven, sino que esperan vivir: todo lo aplazan": CL45. Agustín se reprocha a sí mismo haber aplazado su conversión, y decir siempre: mañana, mañana...

"La vida feliz es fruto de la sabiduría perfecta (...) la filosofía tiene que ser nuestra defensa. Ella nos exhortará a la decidida obediencia a Dios, a resistir duramente la fortuna; la filosofía te enseñará a seguir a Dios, a soportar el hado": CL16.

"A la pobreza le basta con satisfacer las necesidades urgentes; ¿por qué, pues, rechazas este comensal del cual los ricos sensatos imitan las costumbres? Si quieres cultivar el espíritu es preciso que seas pobre o que te hagas semejante a los pobres. El estudio de las cosas saludables no puede hacerse sin atender a conservar la frugalidad, y la frugalidad no es más que una pobreza voluntaria": CL17. Según Agustín en la Regla 3,1:"En cuanto la salud lo permita, someted vuestra carne con ayunos y abstinencia en la comida y la bebida"... Y, Séneca: "Comienza a tener trato con la pobreza: 'Osa, huésped mío, menospreciar la riqueza y aun hacerte digno de Dios"': CL18.

"'Primero -dice Epicuro- es menester considerar con quién comes y bebes, antes de considerar lo que comes y bebes, pues comer y beber sin un amigo es vivir como los leones y los lobos"”: CL19. Así: "Desde que os sentéis a la mesa hasta que os levantéis" (...) "Y no sean sólo vuestras bocas las que reciben el alimento, sino que también vuestros oídos sientan hambre de la palabra de Dios": Regla 3,2. "Si pretendes -le decía Epicuro- enriquecer a Pitocles, no precisas aumentarle el dinero, antes aminorar sus apetencias" (CL21), "pues más vale necesitar menos que tener más": Regla 3,5.

"Algunos ahorran en casa, pero fuera de ella se esponjan en toda suerte de ostentaciones": CL20. Epicuro decía: "Jamás he pretendido agradar al pueblo; porque lo que yo sé no le agrada, y lo que le agrada no lo sé": CL29. La filosofía debe ayudarte a: "Que prefieras gustar a ti mismo antes que gustar al pueblo; que no cuentes los juicios, sino que los sopeses": CL29. "Créeme, la verdadera alegría es austera" (...) "Aspira al verdadero bien y gózate en lo tuyo. ¿Qué quiero decir con este 'tuyo'? En ti mismo y en la mejor parte de ti": CL23. S. Agustín aconseja gozarse en Dios...

Por lo demás, dice Séneca: "Ignoro si voy a sacar algún provecho, pero prefiero que me falte el éxito que la fe": CL25. Y: “'Haz', dice, todas las cosas como si Epicuro te estuviese mirando". Y amonesta Epicuro: "Más que nunca debes retirarte en ti mismo cuando te veas forzado a ponerte en contacto con la turba"': CL25. 
"Lo más importante no es a dónde vas, sino quién eres tú que vas. Es menester vivir con este convencimiento: 'Yo no he nacido para un rincón, mi patria es todo el mundo" (...) "Ahora en realidad, no viajas, vas errante, eres impelido, y cambias de lugar, de un sitio a otro, siendo así que lo que buscas, es decir, vivir bien, se encuentra en toda partes": CL28. "Principio de la salud es el conocimiento del pecado'. Egregia me parece esta sentencia de Epicuro, pues quien ignora que ha pecado no quiere corregirlo; antes que quepa la enmienda debes reconocer tu culpa. Algunos se jactan de sus vicios": CL28.

"¿Qué es, pues, el bien? La ciencia. ¿Qué es el mal? La ignorancia”: CL31. La Naturaleza nos procura bienes que nos conducen a Dios, pero las posesiones no nos asemejan a Dios 'porque Dios no tiene nada'. Nuestros padres expoliaron a otros para enriquecernos: "todo lo que te traspasaron tuvieron que sustraerlo a otro": CL32.

Séneca se enorgullece de Lucilo: "Yo te reivindico para mí: eres obra mía": CL34. Y la carta a los Efesios dice: "somos hechura suya": Ef. 2,10. Según este texto, se podría decir que reivindicarse a sí mismo, que preguntaba Foucault a Hadot, sería construirse a sí mismo, hacerse a sí mismo, y gozarse en sí mismo o "gózate en lo tuyo" (...) "En ti mismo y en la mejor parte de ti": CL23.

Así, sábete que: "Gobernarás a muchos hombres si la razón te gobierna a ti": CL37. "Los preceptos se comportan como las simientes: son pequeños, pero producen mucho": CL38. Según el Evangelio: El reino de los cielos es semejante a un grano de mostaza....

"Dios se halla cerca de ti, está contigo, está dentro de ti. Sí, Lucilo; un espíritu sagrado reside dentro de nosotros, observador de nuestros males y guardián de nuestros bienes, el cual nos trata tal como es tratado por nosotros": CL41. Regla 4,6: "Pues Dios, que habita en vosotros, os protegerá también de este modo, sirviéndose de vosotros mismos". "Tente, empero, por feliz cuando puedas vivir a la vista de todo el mundo, cuando tus paredes te cobijen sin ocultarte; bien al contrario de cuando creemos que nos envuelven, no para que podamos vivir más seguros, sino para que podamos pecar más ocultamente": CL43. Así en la Regla 4,5: "pero en la hipótesis de que su acción quede oculta y nadie la vea, ¿qué hará respecto a quien la observa desde lo alto a quien nada puede quedar oculto?".

"Quien se posee a sí mismo no pierde nunca nada; pero, ¿a cuántos ha sido concedida esta posesión?": CL42. El noble es: "El que ha recibido de la Naturaleza una buena disposición para la virtud": CL44. Esto es "lo que nos promete la filosofía: hacernos igual a Dios. A esto he sido invitado, a esto he venido; ateneos a lo que habéis prometido": CL 48. Entonces: "Sed imitadores de Dios como hijos queridos": Ef. 5,1. 
La seguridad firme e inconmovible confianza, eso es la vida feliz: CL44. "'Es esclavo', pero puede ser libre en espíritu": CL47. "Quién es venerado es amado; el amor no puede mezclarse con el miedo": CL47. Según Regla 7,3:"Lleve con agrado mantener la disciplina, infunda temor. No obstante, aunque una y otra cosa sean necesarias, desee más ser amado por vosotros que temido, pensado que ha de dar cuenta a Dios de vosotros".

"La amistad establece entre nosotros comunidad de bienes: ninguna adversidad ni prosperidad afecta a uno sólo de los dos, puesto que tenemos una misma vida. No es posible que viva feliz quien no dirige sus ojos más que a sí mismo y todo lo refiere a la propia utilidad: si quieres vivir para ti mismo es menester que vivas para otro”: CL48. Dice S. Agustín: “iQué expresión más feliz la de aquel que dijo de su amigo que era 'la mitad de su alma': (Horacio, Odas 1,3-8)!": Conf. 4,6.

"El mal nos posee a todos por adelantado: aprender la virtud es desaprender los vicios": CL50. Aníbal, vencedor de los romanos, fue vencido por los vicios: CL51. "Fuerzo al espíritu a estar atento a mí mismo, sin distraerme en las cosa externas, aunque fuera de mí resuene todo, con tal que en el interior no haya ningún tumulto, con sólo que la avaricia y la lujuria no armen alboroto ni se maltraten entre sí. Porque ¿de qué sirve el silencio en derredor si las pasiones rugen?": CL56.

"Todos tienden en verdad al goce, pero ignoran en absoluto el goce grande y estable" (...) "Reflexiona, pues, que el efecto de la sabiduría es una alegría siempre igual. El alma del sabio es como la del mundo superior a la Luna, donde siempre reina la serenidad": CL59. Los que Salustio llama "servidores del vientre" son más animales que hombres: CL60. S. Pablo, habla de ciertos hombres "cuyo Dios es el vientre" (Fil.3,19). "Quien acepta los mandamientos de buen grado, se libra de la parte más amarga de la esclavitud, o sea de tener que hacer lo que no queremos": CL61. Agustín desea servir por amor, "pues, queramos o no queremos, siervos somos"...

Todas las cosas vienen de la Naturaleza y de Dios: "Dios las rige, y envolviéndolo todo por todas partes, ellas obedecen a su moderador y guía". Así, "el Espíritu envolviéndolo todo", rige todo... "Una sola es, empero, la regla que se aplica a las virtudes humanas, una cosa es la simple y recta razón: no hay nada más divino que lo divino, ni hay nada más celeste que lo celeste" "Y la razón no es otra cosa que una parte del espíritu divino inmerso en el cuerpo del hombre. Y si la razón es divina, y sin razón no hay ningún bien, todo bien es divino": CL66.

¿Qué significa el ocio?: "Ten por bien entendido que nunca se halla más ocupado el sabio que cuando contempla ante sus ojos las cosas divinas y humanas" (...) "Al retirarte no debes procurar que los hombres hablen de 
ti, sino que seas tú quien hable contigo mismo" (...) "Atiende sobre todo a lo que en ti sientas más débil" (...) "Así, en nuestra alma existen algunos miembros enfermos a los cuales hemos de aplicar curación ¿Qué hago en mi ocio? Busco curación a mis dolencias": CL68. Una máxima de Epicuro dice: "Vive retirado"...

"Pero ya sabes que no debemos aferrarnos a la vida, pues la buena cosa no es vivir, sino vivir bien" (...) "Siempre piensa en la calidad, no en la cantidad de vida": CL70. "El alma grande tiene que obedecer a Dios y soportar sin vacilaciones todo aquello que la ley del Universo dispone. $\mathrm{O}$ es conducida a una vida mejor con tal de morar más luminosa y tranquila entre los dioses, o cuando menos, se refundirá sin gran molestia en la Naturaleza y penetrará de nuevo en el gran todo" (...) "Sócrates decía que la verdad y la virtud son la misma cosa": CL71.

Así, se debe enseñar "en poquísimas palabras: el único bien es la virtud: sin ella no existe ningún otro, y reside en la mejor parte de nosotros, en la parte racional" (...) “Tengamos, pues, constancia y perseverancia; nos quedan aún más enemigos de los que hemos vencido, pero ya es una buena parte del progreso querer progresar. En mí mismo tengo conciencia de ello: quiero, y quiero con toda el alma. También veo que eres arrastrado a alcanzar la más grande de las bellezas": CL72.

"La suprema felicidad no se ha de situar en la carne: los bienes verdaderos son los que la razón procura; éstos son sólidos y permanentes, no pueden ser perdidos ni tan sólo decrecer o disminuir": CL74. Usémoslos sobriamente, sin que de ello nos alabemos, como de cosas confiadas a nuestra custodia y que pueden perderse. Todo aquel que las posee sin buen juicio las conserva poco tiempo, pues la felicidad, si no es templada, se destruye ella misma. "Aquel que confía demasiado en los bienes fugacísimos es presto abandonado por ellos, y si no abandonado, afligido": CL74. S. Agustín pide que: "en el uso de los bienes exigidos por las necesidades de esta vida pasajera, ha de prevalecer la caridad que no pasa": Regla 5,2.

"Plazca al hombre todo lo que place a Dios; sienta admiración de sí mismo y de sus cosas, por cuanto no puede ser vencido y puede tener los males bajo sus pies y someter con la razón, la más fuerte de todas las cosas, el azar, el dolor y la injuria. Ama la razón, y este amor te armará contra los ataques más terribles”: CL74. “¿Qué es lo mejor del hombre? La razón, pues a causa de ella aventaja a los animales y queda situado inmediatamente después de los dioses": CL76. Cf. en Agustín: La razón, don de Dios: carta 120.

A uno, que le pidió morir, C. César le respondió ‘¿Es que acaso vives?’. "He aquí lo que precisa responder a aquellos para los cuales la muerte sería 
un beneficio: ‘ ¿Temes la muerte? Pero ¿es que acaso vives?’”: CL77. Y, Agustín: ¿¿Dices que quieres ser perfecto; pero es que acaso vives?”: Soliloquios 1,1 .

"Pues si la maldad hace desgraciados y la virtud felices, y si el agradecimiento es una virtud, has restituido una cosa ordinaria y has alcanzado otra inestimable, la conciencia del agradecimiento, que no puede recaer más que en un alma divina y feliz": CL81. Por lo demás: "Ocio sin letras es una muerte, es la sepultura de un vivo”: CL82. Y, de otra parte:“ ¿De qué sirve tener secretos para los hombres? Nada queda cerrado para Dios. Él está presente en nuestras almas e interviene en nuestros pensamientos": CL83.

"Si el único bien es la honestidad, todos concederán que es suficiente para vivir feliz; recíprocamente, no se negará que si la sola virtud hace feliz, la honestidad es el único bien". "Pues la vida feliz implica el bien perfecto e insuperable, y si es así, tiene que ser perfectamente feliz. Si la vida de los dioses no tiene nada mayor o mejor, y la vida feliz es vida divina, no existe, por lo tanto, nada que pueda reportarle crecimiento": CL85.

“¿Quieres saber qué es el mal? Ceder ante esas cosas que llamamos males, abatir ante ellas nuestra libertad, por la cual se ha de pasar por todas las penas": CL85. Pero dice: "He avanzado poco: todavía no me atrevo a patentizar mi frugalidad, aún me preocupo de la opinión de los viandantes” (...). “QQuieres saber qué cosa constituye al sabio? La misma que constituye a Dios. Es forzoso que le reconozcas algo divino, celestial, magnífico (...) ¿Quieres saber cuál es el país del bien supremo? Es el alma, en la cual si no es pura e inviolable al mal, no hay lugar alguno para Dios": CL87.

" Pobreza no es poseer pocas cosas, sino no poseer muchas; recibe, pues, el nombre no de aquello que tiene, sino de aquello que le falta"': CL87.

Dices que sabes medir todo: ¿Si tan hábil eres, mide el alma humana, muéstrame su grandeza y pequeñez. Tú sabes cuál es la línea recta? ¿Qué sacarás si ignoras la rectitud de vida?”..."¿De qué sirve dominar a un caballo y moderar con el freno su carrera cuando se es arrastrado por las pasiones desenfrenadas?". "Cualquiera que sea la parte de las cosas humanas y divinas que te sea dable alcanzar, quedarás anonadado por una enorme multitud de problemas y doctrinas": el tema del alma: origen, naturaleza y fin. "Toda la Naturaleza es una sombra o vana o engañosa": CL88.

"La mayoría de los autores, y los más ilustres, dividen la filosofía en tres partes: 'moral', 'natural' y 'racional'": CL89. Así lo ha recordado Hadot. En cuanto a la filosofía, que es un don de los dioses: "Su única tarea es la de descubrir la verdad en las cosas divinas y en las humanas. Nunca se 
aparta de ella la religión, el amor a la gente propia, la justicia y cualquier otro cortejo de virtudes que se dan la mano, forman un todo. Nos enseña el culto a los dioses, el amor a los hombres, y que el imperio es cosa de los dioses y el compañerismo cosa de los hombres, compañerismo que algún tiempo fue respetado, antes que la avaricia quebrara la sociedad y se convirtiese en causa de pobreza aun para aquellos que se habían enriquecido con desmesura; ya que desde que quisieron cosas propias dejaron de poseerlas todas" (...) "Mandar era cumplir un deber, y no, tener un reino": CL90.

"La sabiduría tiene su morada más en lo alto; ella es dueña, no de las manos, sino del alma" (...) "Ella fomenta la paz e invita al linaje humano a la concordia (...) Esas son las iniciaciones mediante las cuales nos abre no un templo ciudadano, sino el Universo, templo grandioso de todos los dioses, las verdaderas imágenes y fieles representaciones de los cuales nos permite contemplar con los ojos de la inteligencia, pues el ojo corporal es torpe para tan grandioso espectáculo. De aquí vuelve al principio de las cosas, a la razón eterna incorporada al todo, y a la virtud de las simientes, que da a cada cosa su forma apropiada. Después penetra en el estudio del alma, de su origen, de su morada, de su duración y del número de partes en que puede dividirse": CL90.

Además: "la razón divina manda a todas las cosas y no es mandada por ninguna: de igual naturaleza es nuestra razón, porque de ella procede. Si convenimos en esto, convendremos también en otra cosa: en que la vida feliz radica en el hecho de que nuestra razón es perfecta" (...) "el alma del sabio tiene que ser tal como correspondería a un dios": CL92.

Del mismo modo, en el estado más glorioso dado por Dios al linaje humano:

“...por ningún cultivador eran poseídas las tierras/

y no era permitido limitar, ni poner a los predios

mojones; los hombres recolectaban por doquier/

y la tierra lo daba todo liberalmente sin que le fuese pedido”.

¿Quién más feliz que aquella generación humana? Aquellos hombres gozaban en común de la Naturaleza, la cual bastaba como madre y defensora de todos: así era segura la posesión de las riquezas públicas. ¿Cómo no considerar ya más rica la Humanidad de aquellos tiempos en que era imposible encontrar un pobre?". "No era menor el gozo de encontrar los frutos de la naturaleza que de mostrar el hallazgo a los demás; y así no podían faltar ni sobrar a nadie, porque eran repartidos en concordia": CL90. Los Hechos de los Apóstoles, y S. Agustín recuerdan que no había pobres entre los cristianos, pues el que tenía repartía y no le sobraba, y al pobre no le faltaba. 
Quién encierra en su cuerpo virtud y valor "se iguala a los dioses y a ellos tiende, recordando su origen. Para nadie puede ser un crimen pretender subir al lugar de donde se ha bajado. ¿Y por qué no has de creer que hay algo divino en aquel que es una parte de Dios? Este Universo que nos contiene es un solo ser y es Dios: somos compañeros y miembros suyos. Grande es el alcance de nuestra alma, pues a Dios se remonta si no la traban los vicios" (...).

"Ir al cielo sería harto trabajo, pero es que el alma vuelve a él" (...) "Ya te digo que las riquezas se encuentran en otro lugar diferente de aquel donde las atesoran; no es el cofre lo que debemos llenar, sino el alma" (...).

"No suplico a nadie las exequias postreras, no confío a nadie mis restos. La propia Naturaleza ha previsto que nadie quedase insepulto: el tiempo enterrará a quien haya sido abandonado por la crueldad humana'. Dice Mecenas: "la Naturaleza, a los abandonados entierra"”: CL92.

"Conoces que es necesario cultivar inviolablemente la amistad, pero no lo haces; sabes que es iniquidad exigir castidad a tu mujer cuando tú corrompes la de los demás; sabes que tal como ella no ha de tener ningún trato con el adúltero, tampoco tú con tu amiga, y lo tienes": CL94. Agustín repudia la aceptación romana del adulterio del varón.

M. Agripa decía: "Con la concordia crecen las cosas pequeñas. Con la discordia se hunden las grandes'. De esta sentencia decía que le había hecho un excelente hermano y amigo" (...).

"El desventurado Alejandro fue arrastrado por un furor de devastar regiones extranjeras que le condujo hasta tierras desconocidas". "No creas que alguien pueda hacerse feliz con la infelicidad de los demás": CL94. Por lo demás: La ambición de Alejandro, le hizo infeliz por no conquistar toda la tierra y fue vencido por el vicio: CL 91.

"El hombre, cosa sagrada para el hombre, es muerto ya por juego o pasatiempo; antes era un crimen enseñarle a infligir y recibir heridas, hoy ya se le expone desnudo y sin armas, y el único espectáculo que podemos sacar del hombre es ya la muerte": CL95.

"Es menester que nos propongamos el bien supremo como fin hacia el cual nos esforzamos, hacia el cual se orientan todos nuestros actos y todas nuestras palabras; como los navegantes que tienen que dirigir la ruta hacia una estrella. Vivir sin una finalidad es vivir al azar" (...).

"A Dios sólo se le rinde culto conociéndole" (...) Y, nadie "habrá progresado bastante si no ha concebido de Dios la idea justa, como de quien todo lo tiene y todo lo da, bienhechor gratuito" (...) “¿Quieres tener propicios a los dioses? Sé bueno. Quien les imita les rinde culto suficiente": CL 95.

"Sobre todo debemos facilitar esta fórmula breve de los deberes humanos: es todo uno eso que ves que abarca las cosas divinas y las humanas. 
Somos miembros de un gran cuerpo. La Naturaleza nos ha criado parientes, sacándonos de los mismos principios y destinándonos a los mismos fines. Ella nos infiltra el amor mutuo y nos hace sociables. Ella estableció lo justo y lo injusto; por decreto de ella es más de compadecer quien hace el mal que quien lo sufre; por mandamiento suyo todas las manos han de estar prontas a socorrer a los necesitados. Tengamos en la boca y el corazón aquel verso: 'Hombre soy y nada humano me es extraño a mí'. Tengamos las cosas en común: para esto hemos nacido. Nuestra sociedad es muy semejante a una bóveda que caería si las piedras no se sostuviesen unas a otras: he aquí su capacidad de resistencia": CL95. "Tened vuestra ropa en un lugar común”: Regla 5,1.

"El día que ya no pueda soportar una cosa cualquiera, ya ni a mí mismo podré soportarme": CL96. "Puede el malhechor esconderse, pero no la confianza que pone en permanecer escondido" (...). Así, Epicuro pide luz frente a las obras malas. "La prueba que el horror al crimen nos es natural la hallamos en el propio hecho de que no exista nadie que no experimente temor aun en medio de la seguridad. La fortuna libera a muchos de la pena, pero a nadie del temor": CL97. Dice el Jn Ev., 3,19: "la luz vino al mundo y los hombres prefirieron las tinieblas, por sus malas acciones".

"Espíritu desventurado es el que siente inquietud por el mañana; desgraciado antes de la desgracia es quien anda lleno de ansiedad para lograr que las cosas que le deleitan le alcancen hasta el fin de sus días": CL98. Cristo dice: "No os preocupéis por el mañana que el mañana traerá su afán". "Una misma ley obliga a todos: cuando vemos que alguien nace, sabemos que le está reservada la muerte (...). La vida no es ni bien ni mal, es una ocasión para el bien o para el mal": CL99.

"No es virtud, sino inhumanidad, este de contemplar el entierro de los suyos con los mismos ojos que cuando estaban vivos y no conmoverse en el primer momento de su separación”: CL99. Agustín llora, arrasado en lágrimas, la muerte de Mónica: Conf. 9,12,33. "Desde la infancia somos conducidos a la ancianidad, maduramos para otro alumbramiento. Otro origen nos aguarda, otro estado de cosas". Esta certidumbre de la otra vida llega a expresiones que parecen tomadas de S. Agustín. Así: "Este día, que te asusta tanto por ser el último es el natalicio del día eterno": CL102.

¡Qué locura es que haga planes para una larga vida quien no es dueño ni del mañana! ¡Qué gran demencia son las largas esperanzas de los hombres emprendedores! "Compraré y edificaré, pondré dinero a rédito, cobraré, me encargaré de cargos honoríficos -dicen tales hombres": CL101. Así le acontece al rico del Evangelio: ensancha sus locales para la cosecha pero, de repente, muere... 
"La Naturaleza me ha engendrado amante de todos": CL102. "Antes enséñame cuán natural es dilatar el pensamiento por la inmensidad. Grande y generoso ente es el alma humana que no puede tolerar que le impongan otros límites que los que le son comunes con Dios": CL102. "Grandes son los ámbitos de la memoria”, dice Agustín, que llevan a Dios: Conf. X, 8, 14-5.

Nadie cura de sus propios males huyendo a otros países, pues eso no es viajar sino "andar errante". "Por esto te acongojan en todas partes y en todas partes te consumen con las mismas molestias. El enfermo no tiene que buscar países, sino medicinas (...) Si quieres realizar viajes agradables, cura al que es menester que tengas por compañero": CL104. "La mejor garantía de la seguridad es no cometer ninguna injusticia. Los soberbios llevan una vida complicada y turbulenta; temen tanto como dañan, y no tienen ni un momento de reposo": CL106.

La riqueza está en el alma, no en el patrimonio: "El mortal que menos necesita es el que menos desea. Posee cuanto quiere aquel que sabe querer lo que precisa". Átalo "se ponía a recomendar la pobreza y a demostrar que todo lo que excede de lo necesario es un peso inútil y gravoso, muchas veces había yo deseado salir pobre de la escuela": CL108.

Los dioses, "son clementes y favorables para todo aquel que se ha reconciliado consigo mismo". "Todo aquello que tenía que sernos un bien, Dios, padre nuestro, lo puso a nuestro alcance. No aguardó que nosotros lo anduviésemos buscando, nos lo dio espontáneamente: en cambio hundió muy profundamente las cosas dañinas": CL110.

Muchos son felices por conquistar dominios, pero: "Dominarse a sí mismo es el mayor de todos los dominios. Enseñadme qué cosa sagrada es la justicia, siempre atenta al bien ajeno, no exigiendo de ella otra cosa sino que sea ella misma. Ante todo, que cada uno diga: es menester que yo sea justo desinteresadamente": CL113.

"Trata de contemplar el fin de todas las cosas y abandonarás las superfluidades" (...) "Nunca es poco lo que es suficiente, y lo que no es bastante nunca es mucho. Después de vencer a Darío y a los indios, Alejandro era pobre": CL119. "Así como cualquier naturaleza no presenta su bien hasta que ya está cumplida, igualmente el bien del hombre no está en éste hasta que posee la razón perfecta. ¿Y qué bien es éste? Yo te lo diré: un alma libre y recta que sujete toda cosa a ella y ella a ninguna": CL124.

"Sólo encontramos el bien donde hay razón. Existen cuatro especies de naturalezas: la del árbol, la del animal, la del hombre y la de Dios; las dos últimas, que son racionales, tienen la misma naturaleza, y lo que las distingue es que una es inmortal y la otra mortal": CL124. 
¿Cuál es el bien del hombre?: "El alma rectificada y pura émula de Dios, elevada sobre las cosas humanas y sin que sitúe ningún bien fuera de ella misma. Eres un animal racional. ¿Cuál es, pues, tu bien? La razón perfecta" (...) "Te procuraré una fórmula breve para medir tu progreso, con la cual conocerás si eres perfecto: habrás alcanzado tu bien cuando comprendas que los más infelices son los más felices": CL124. Agustín lamenta que los mendigos y borrachos que él encontraba por la calle le parecían más felices que él con toda su sabiduría mundana y todos sus estudios liberales que deberían haberle hecho un hombre libre.

\section{La vieja sabiduría de Aristóteles}

Como es bien conocido, Aristóteles llega a Agustín, principalmente, a través de Cicerón. Pero, de todas maneras, podemos rastrear, en Aristóteles, algunos problemas especialmente cercanos a Agustín. Quizá el tema más famoso de todos, sea el problema del tiempo, que ya hemos tratado en otro lugar ${ }^{11}$. Siempre se ha supuesto que es un tema creado, en exclusiva, por el genio de Agustín. De modo que hasta B. Russell ha protestado, amargamente, contra las ediciones de Las Confesiones que suprimen los libros XI a XIII, alegando, precisamente, su enorme dificultad por este tema del tiempo. Para Russell, el libro XI es el más genial de toda la obra, mientras se nos comentan, continuamente, el robo de las peras y otros detalles inútiles e insustanciales.

Otros temas que fluirán de Aristóteles a Agustín, a través Cicerón, son el tema de la amistad, el problema de la felicidad y el de la virtud: "Pero vivir bien y obrar bien es lo que llamamos ser dichosos; y así ser dichoso o la felicidad sólo consiste en vivir bien, y vivir bien es vivir practicando la virtud. En una palabra, la felicidad y el bien supremo constituyen el verdadero fin de la vida"12. Para Agustín, la felicidad y la virtud consiste en buscar y encontrar a Dios...

"Todo mundo conviene en que la salud es un bien (...). Pero cabe engaño respecto a los medios que conducen a este fin, y así se pregunta si es bueno para la salud comer o no comer tal o cual cosa. El placer y la pena son, principalmente lo que en estos casos nos hacen incurrir en equivoca-

${ }^{11}$ D. Natal, "La Sabiduría de los clásicos en san Agustín: Quintiliano de Calahorra y su 'Institutio oratoria”, Revista Agustiniana 50 (2009) 586-591.

${ }^{12}$ Aristóteles, Moral: La gran Moral=GM. Moral a Eudemo $=$ ME. Traducción de Patricio de Azcárate, Madrid 1976, 6ª ed. GM, 1,4. 
ción y en faltas, porque huimos de la última y corremos tras el primero": GM 1,17. Por lo que se refiere al cuerpo, "si se quiere curar una salud resentida, es preciso seguir un régimen y reducirse, por lo pronto, a una pequeña cantidad de agua y de alimentos": GM 2,5. Así: "los enfermos necesitan recibir menos alimento para no empeorar, pero una ve $z$ superada la enfermedad"...: Regla 3,18.

"El incontinente es el que cree que lo que hace es excelente y le es muy útil, y no tiene en sí mismo una razón que sea capaz de oponerse a los placeres que le seducen y le ciegan. El intemperante, por el contrario, siente en sí la razón que se opone a sus extravíos en aquellas cosas a que le arrastra su funesta pasión": GM 2,8.

Ahora bien, por lo que respecta a la amistad: "Sería un absurdo creer que los buenos no son tan capaces como cualquiera otro de vivir en intimidad con los demás, y como no puede menos de haber placer en esta intimidad, debemos concluir que los hombres de bien, más que nadie, son agradables los unos a los otros": GM 2,13.

Por lo demás, nos amamos a nosotros mismos, pues: "Para nosotros mismos, principalmente, podemos querer el bien, desear una larga vida, y una vida dichosa; nos somos simpáticos sobre todo a nosotros mismos, y sobre todo queremos vivir con nosotros mismos" (...) "En efecto, como ya hemos indicado, cuando queremos expresar a uno de nuestros amigos que es nuestro amigo íntimo, decimos: 'mi alma y la tuya no forman más que una": GM 2,13. Los fieles son "una sola alma, la única alma de Cristo".

Así: “Mi amigo es otro yo’; y para expresar que se le ama con ardor, se repetirá con el proverbio: “"Es otro, Hércules; es otro yo'. Nada más difícil, como han dicho algunos sabios, y al mismo tiempo más dulce, que el conocerse a sí mismo, porque ¡qué encanto hay en conocerse!” (...) “Así como cuando queremos ver nuestro propio semblante nos miramos en un espejo, así cuando queremos conocernos sinceramente es precioso mirar a nuestro amigo, en el cual podemos vernos perfectamente, porque mi amigo, repito, es otro yo": GM 2,17. El hombre independiente necesita la amistad para conocerse a sí mismo y para compartir los bienes: GM 2,17. Pero, el hombre de bien: "Es amigo del bien mucho más que amigo de sí mismo, y no se ama personalmente, sino porque es bueno”: GM 2,16. Agustín: ¡Feliz el que te ama a ti, al amigo en ti y al enemigo por ti": Conf.4,9, 14.

Como hay 3 elementos que definen al hombre: el poder, la riqueza y el placer, hay 3 formas de vida: la vida política (gloria), la vida filosófica (contemplación) y la vida del placer (gozo). Pero "el hombre que realiza con pureza y sin trabajo todos los deberes de la justicia, o que puede elevarse hasta la contemplación divina es todo lo dichoso que consiente la con- 
dición humana": ME 1,4. La felicidad es el ser "de una vida completa conforme a la virtud": ME 2,1.

La virtud es el justo medio. Así, la amistad se opone a la fanfarronería y la disimulación, la magnanimidad a la vanidad y la bajeza, la dulzura a la ira y la pasividad: ME 2,3. "Por consiguiente, todas las virtudes son consecuencia de la magnanimidad, o la magnanimidad es la consecuencia de todas las virtudes": ME 3,5.

Con todo, es bien sabido que: "Lo que es común a muchos obtiene un mínimo de cuidado. Pues todos se preocupan de sus cosas propias, y menos de lo común, o tan sólo en lo que les atañe"13. Por eso, para san Agustín, cuando tratemos las cosas comunes mejor que las propias, sabremos que hemos adelantado en la virtud: Regla V, 31 .

Ahora bien, sin amistad no hay vida: "debe observarse que un amigo nos parece el más precioso de los bienes de la vida, y que la privación de amigos, el aislamiento, es la cosa más terrible, porque ni la vida entera ni las relaciones voluntarias son posibles sin los amigos": ME 7,1. Muerto su amigo, dice Agustín: “¡Qué angustia ensombreció mi corazón! Todo cuanto veía era muerte. Mi ciudad natal se me convirtió en un suplicio, la casa de mis padres era una desolación pasmosa": Conf. IV, 4, 9.

Por eso: "Sea pues, amor la voluntad de querer para alguien lo que se piensa que es bueno -por causa suya y no de uno mismo-, así como ponerlo en práctica hasta donde alcance la capacidad para ello. Además, es amigo el que ama y es, a su vez amado. Y también se consideran amigos los que creen estar mutuamente en esta disposición"14.

"Además (se ama) a aquellos que nos deleitan con su trato y compañía, como son los complacientes o los que no reprueban los errores que cometemos ni son amigos de disputas o pendencieros (pues todos estos son reñidores y los que riñen ponen con ello de manifiesto que quieren lo contrario que uno), así como los que tienen tacto lo mismo para hacer chistes que para aguantarlos, ya que en ambos casos se produce con ellos una rápida camaradería, por ser, como son, capaces de admitir una broma y de gastarla de un modo conveniente": R II, 1381ª 29-35. Algunos están pendientes "sólo de las cosas buenas, ya que eso es lo que hace al hombre bueno" frente a los pendencieros. "También (se ama), en fin, a quienes no

13 Aristóteles, La Política. Ed., C. García Gual y A. Pérez Jiménez. Editora Nacional, Madrid 1981, 3ª, II, III, p. 80.

${ }^{14}$ Aristóteles, Retórica. Introducción, traducción y notas de Quintín Racionero. Gredos, Madrid 1990. II, 1381a, 40, p. 327-8). En adelante R. 
nos causan miedo y a quienes nos inspiran confianza, porque nadie ama a aquel que teme": R II, 1381b, 30.

En fin, que "la amistad es una virtud o algo acompañado de virtud, y además, es lo más necesario para la vida. En efecto, sin amigos nadie querría vivir, aunque tuviera todos los otros bienes"15. Los amigos son: "Dos marchando juntos' (Ilíada X 224), pues con amigos los hombres están más capacitados para pensar y actuar": EN $1155^{a}, 15$. “Además, como dice Teognis, la convivencia con los hombres buenos puede producir una especie de práctica en la virtud": EN 1170", 10-11.

"Ahora bien, ¿no es verdad que para los amigos el convivir es lo más deseable?" (...) "Y lo que cada hombre considera que es la existencia o aquello que él prefiere para vivir, esto es en lo que desea ocuparse con los amigos y, así, unos beben juntos, otros juegan juntos, otros hacen ejercicios, o cazan, o filosofan juntos, y, en cada caso, los amigos pasan los días juntos con aquellos que más aman en la vida; porque queriendo convivir con los amigos, hacen y participan en aquellas cosas que creen que producen la convivencia"(...) "la amistad de los hombres buenos es buena, y crece con el trato, y parece que incluso se hacen mejores actuando y corrigiéndose mutuamente -porque toman entre sí modelo de lo que les agrada, de aquí la expresión: 'los hombres buenos aprenden de las cosas buenas"': EN 1172a,1-14.

"Recuérdese que hay tres especies de amistad; primero, amistad por virtud; después, por interés; y, al fin, por placer". Sólo la primera es verdadera amistad: "El amigo ama al amigo por él mismo, y no por otra cosa que no es él; y, por consiguiente, si no goza en cuanto es virtuoso y bueno, la relación que los une no es la primera y perfecta amistad": ME 7,2. S. Agustín invita a amar a Dios en los amigos y a los amigos en Dios.

"Así, pues, lo que es bueno absolutamente es también absolutamente agradable, por una ley de la naturaleza, y complace a aquellos para quienes es un bien": ME 7,2. (...) "No hay amistad sólida sin confianza, y la confianza se adquiere con el tiempo": ME 7,2. Si no se ama a las personas más que a las cosas, "no es posible que todo llegue a ser común entre amigos": ME 7,2. En cualquier caso: "todos los hombres sin excepción tienen en sí mismos alguna pequeña parte de bien": ME 7,2." La amistad es una igualdad; los amigos verdaderos no tienen más que un alma'”: ME 7,6.

Hay países donde los amigos no pueden recurrir a los tribunales: "Esta ley es muy sabia, puesto que los hombres de bien no acuden, naturalmente,

${ }^{15}$ Aristóteles, Ética Nicomaquea. Introd. E. Lledó. Trad., y notas J. Pallí Bonet. Gredos, M.1993, 2a reimpresión, VIII, 1155ª 1-5. En adelante EN. 
a la justicia de los tribunales y, como hombres de bien, han tratado a los que se encuentran en este caso": ME 7,10. Pablo lo reprocha a los cristianos...

"Vivir es sentir y conocer, y por consiguiente, vivir juntos es sentir juntos y conocer juntos": ME 7, 12 (...) "es un gran placer el estar juntos, y gozamos más de nuestra felicidad haciendo partícipes de ella a nuestros amigos hasta donde podamos, y dándoles siempre lo mejor que tenemos" (...) "Pero es una felicidad mucho mayor el disfrutar juntos placeres más elevados y más divinos": ME 7,12.

Si es grato ser dichoso, la vida común tiene la ventaja de obrar en concierto: "la sociedad de hombres eminentes, unidos por al amistad, es la cosa más grata del mundo. Consagrarse juntos a esas nobles contemplaciones o a estos delicados goces, tal es el fin de estas amistades" (...) "Es preciso confesar, pues, que el hombre está hecho para vivir en sociedad con sus semejantes, que realmente todos los hombres buscan la vida común, y que el hombre más dichoso y el mejor de todos es el que la busca con más empeño": ME 7,12. Para Agustín un signo de virtud es: "cuanto cuidéis mejor lo que es común que lo propio": Regla 5, 31. En las penas y alegrías: "nada debe ser para un amigo más penoso, así como nada más dulce, que la presencia de su amigo": ME 7, 12.

Y, al fin: "algunos pretenden que el semejante es amigo del semejante, de donde se dice: "la divinidad conduce siempre al semejante hacia el semejante” (Odisea XII 218)16. "Pero los malos prefieren los bienes naturales a un amigo: ninguno de ellos ama a las personas más que a las cosas. Y, así, no son amigos, porque no tiene realidad el proverbio, 'las cosas de los amigos son comunes'; el amigo resulta ser un accesorio de las cosas, y no las cosas un accesorio de los amigos": EU VII, 1237b, 30.

"En efecto, dividida la amistad según tres modos, la benevolencia no se encuentra ni en la amistad fundada en la utilidad ni en la amistad fundada en el placer": EU VII, 1241ª 3-6. "Ahora bien, percibir y conocer a un amigo debe ser, en cierto modo, percibirse y conocerse a sí mismo" (...) "Pero si se debe vivir bien y también el amigo, y vivir en común incluye el actuar en común, la comunidad se centrará principalmente en las cosas incluidas en el fin": EU VII, 1245ª 25-6, 1245b, 1-4.

Y, en definitiva: "el elemento divino que hay en nosotros", tiene especial capacidad para conocer y decidir: ME 7,14. "Es uno moralmente bello y virtuoso, es decir, perfecto hombre de bien, cuando sólo busca los bienes

16 Aristóteles, Ética Eudema. Introd. E. Lledó. Trad., y notas J. Pallí Bonet. Gredos, M.1993, 2 a reimpresión, VII, $1235^{\mathrm{a}}, 8-10$. En adelante EU. 
bellos por sí mismos, y practica las bellas acciones excesivamente porque son bellas, entendiendo por acciones bellas la virtud y los actos que la virtud inspira" (...) "Por tanto, la belleza moral, la hombría de bien, es la única virtud verdaderamente completa": ME 7,15.

Y, en una palabra: "los bienes, serán tanto mejores cuanto más nos permitan conocer y contemplar a Dios": ME 7,15. Y, Agustín termina: "Que el Señor os conceda cumplir todos estos preceptos con amor, como amantes de la Belleza espiritual (Si 44,6) y prendados, con una vida santa, del buen olor de Cristo (Ct 1,3), no como siervos bajo la ley, sino como personas libres que viven bajo la gracia": Regla 8,1.

\section{La Filosofía como cura de almas en las Tusculanas de Cicerón}

La filosofía es conocimiento del mundo físico (física), discernimiento y vida moral (ética) y coherencia de argumentación y juicio (lógica) ${ }^{17}$. Para Cicerón no hay medias tintas en el estudio de la filosofía, pues sería vergonzoso mostrar fatiga en la "búsqueda de la verdad": T., Introd., 57; 73.

Ahora bien, los Prólogos de las Tusculanas muestran que: "la función primordial de la filosofía es la terapia del alma":T., Introd., 60; 84. Así, se presenta la filosofía como medicina del alma: "Para ello, ya que hemos iniciado el tratamiento, confiémonos a sus cuidados; si queremos, nos curaremos": T III, 6,13. Igual dice T II, 4,11:"en realidad este es el efecto que produce la filosofía: cura las almas, hace desaparecer las preocupaciones, libera los deseos, disipa los temores".

Y, en T II, 5,13: "Ahora bien, el cultivo del alma es la filosofía; ella extirpa los vicios de raíz, prepara las almas para recibir las semillas", "unas semillas que, cuando se han desarrollado, producen frutos ubérrimos". Por lo demás, la virtud viene de vir (hombre) y supone fortaleza: "Tú me preguntarás quizá de qué modo y con razón; en realidad tal es la medicina que la filosofía proclama poseer": T II, 8,43.

Para A. Medina: Nada destaca más en las Tusculanas que: "la consideración de la filosofía como medicina del alma y alivio y cura de aflicciones y perturbaciones de toda naturaleza": T., Introd., 74. Y, así, se busca vivir bien y ser feliz: "tener en uno mismo toda la ayuda para alcanzar una vida buena y feliz, en una palabra, para ser siempre feliz”: T., Introd., 75. Así, tú

${ }^{17}$ Cicerón, Disputaciones Tusculanas. Introducción, traducción y notas de Alberto Medina González, Madrid 2005, Introd., 51. En adelante T. 
eres: “¡Oh filosofía, guía de la vida, indagadora de la virtud, desterradora de los vicios! ¿Sin ti qué podríamos ser, no sólo nosotros, sino también la vida humana en general? Tú has engendrado las ciudades, tú has llamado a los hombres dispersos a una comunidad de vida, tú los has unido, en primer lugar compartiendo una vivienda, luego mediante el matrimonio, a continuación, mediante la comunión de la escritura y el lenguaje, tú has sido la inventora de las leyes, tú has sido la maestra de la moralidad y el orden";(...) "¿A qué otra ayuda mejor que a la tuya podemos recurrir, tú que nos has regalado la tranquilidad de la vida y nos has suprimido el terror de la muerte?": T V,2,5.

Por tanto: "ocupémonos de estas cuestiones y en particular las que contribuyen al alivio de las aflicciones, los temores y los deseos, porque éste es el fruto más ubérrimo de toda la filosofía": T I, 49,117. Pues: "Existe ciertamente una medicina del alma, la filosofía, cuya ayuda no hay que buscarla, como en las enfermedades del cuerpo, fuera de nosotros, y debemos esforzarnos con todos nuestros recursos y fuerzas para ser capaces de curarnos a nosotros mismos": T III, 3, 6. Y, como sin la filosofía no se cura nuestra alma y sus miserias: "Sometámonos, pues, a su tratamiento, y permitamos que ella nos cure. Porque, mientras estos males estén asentados en nosotros, no sólo es imposible que seamos felices, sino que ni siquiera podemos estar sanos": T IV, 38,84.

Así pues: "No cabe duda que hay una medicina y la naturaleza no se ha mostrado con el género humano tan hostil y enemiga que haya descubierto toda clase de remedios saludables para el cuerpo y ninguno para el alma; en realidad ella le ha prestado mayores servicios al alma, porque, mientras que los remedios que se aplican para el cuerpo vienen de fuera, la salud del alma se halla encerrada en ella misma. Pero cuanto mayor y más divina es la excelencia que reside en el alma, tanto mayor es el cuidado que ella precisa": T IV, 27,58.

Entonces, los antiguos llamaron insania a la falta de salud del alma carente de razón. Y: "No es menor la agudeza que les llevó a llamar amentia (ausencia de razón) y dementia (pérdida de razón) a la afección del alma privada de la luz de la razón": T III, 5,10. Por otra parte, no conviene olvidar que, entre las pasiones del alma, el furor colérico es, también, una gran perturbación del alma. Y, así, "el odio es la ira inveterada": T IV, 9, 21. Así, Agustín aconseja no tener disputas o terminarlas cuanto antes "para que la ira no se convierta en odio" (ne ira crescat in odium): Regla 6,1.

Por lo demás, igual que cuando un experto falla en su propio arte queda más en ridículo: "así también un filósofo que falla en su modo de vivir es más desvergonzado porque resbala en la tarea de la que pretende ser maes- 
tro y porque, aunque se declara un experto en el arte de vivir, falla, sin embargo, en su vida": T II,4,12. Un discurso tan contradictorio resulta, en sí mismo, increíble: T III, 20,48-49. De ahí que, como ha insistido Hadot, la filosofía tiene que ser siempre un modo de vida. Y, si, perdiera su función: "Esta convicción de que sabiduría y vida son indisociables hacía de la filosofía el saber terapéutico por excelencia. El término 'terapia' alude aquí a su función liberadora y sanadora: era 'remedio' para las dolencias del alma"18.

\subsection{Filosofía, Retórica y Terapéutica}

Cicerón se nos presenta como el introductor de la filosofía en Roma: "La filosofía no ha sido objeto de atención hasta nuestros días y no ha recibido ninguna luz de las letras latinas: a mí me toca darle esplendor y vida":T I, 3,6. Y: "así también yo tengo el propósito de, sin abandonar una prístina pasión por la elocuencia, cultivar este arte más elevado y más rico: T I, 4,7. Pues: “¿qué hay, ipor los dioses inmortales!, más deseable que la sabiduría, más trascendente, más útil y más digno del hombre? Los que se entregan con ardor a su consecución se llaman filósofos": Cicerón, Sobre los deberes, II, $5^{19}$.

En fin, según el autor de la Introducción a esta obra: "las Tusculanas son en realidad un monólogo filosófico aderezado con todos los ingredientes de la retórica, por no decir, lo que sería aún más exacto, que ellas son en puridad un discurso retórico de contenido filosófico-moral":T., Introd.,78. Cicerón se ha considerado, siempre y sobre todo, "un orador y, por ello, ha querido poner a prueba su arte creando un discurso retórico de contenido filosófico-moral": T., Introd., 78-9.

Además, cada elemento del mundo tiende a su centro (kéntron), "por su propia tendencia y peso": T I, 17,40. Así, el alma es una quintaesencia alejada de la tierra: T I, 17,41.Y sus elementos: "no tienen nada que les atraiga hacia abajo y se dirigen siempre hacia lo alto": T I, 18,42. Agustín habla de "caer hacia lo alto", pues, cada cosa tiene su peso y medida, y el peso del hombre es el amor: “Amor meus pondus meum”: Conf. 13,9.

$\mathrm{Y}$, si "en nuestras mentes hay ínsito un deseo innato insaciable de ver la verdad" que nos inclina a "las cosas celestes, aumentará también en nosotros el deseo de conocerlas" (T I, 19,45), hasta que el alma, "liberada, haya alcanzado el lugar al que su naturaleza le impulsa": T I, 20, 47. Pues: "el alma, sea hálito vital o fuego, es divina": T I, 25,60; I,26,65. "En consecuen-

\footnotetext{
${ }^{18}$ M. Cavallé, La sabiduría..., 14

${ }^{19}$ M. Cavallé, La sabiduría..., 25
} 
cia, cualquiera que sea la naturaleza de lo que siente, conoce, vive y es activo, debe ser necesariamente celeste y divina y, por esa razón eterna": T I, 27,66. Agustín dice: el que ama la tierra es tierra y si ama el cielo, cielo.

"En cuanto a la filosofía, madre de todas las artes, ¿qué otra cosa es sino, como dice Platón, un regalo, o como sostengo yo, un hallazgo de los dioses?": T I, 26,64. Nos da el culto, el derecho, la convivencia y la grandeza de alma: "La sabiduría es la ciencia de las cosas divinas y humanas y el conocimiento de cuál es la causa de cada cosa; la consecuencia de ello es que ella imita las cosas divinas, mientras que considera todas las cosas humanas inferiores a la virtud": T IV, 26,57.

Y, como la belleza corporal implica armonía entre sus miembros, la belleza del alma es equilibrio y coherencia de opiniones y juicios en una "firmeza y estabilidad, que es consecuencia de la virtud o que contiene la esencia misma de la virtud": T IV, 13,30.

En fin, Cicerón nos asegura: "A los detractores de la filosofía en su conjunto les he respondido en el Hortensio". Y, ha defendido la Academia, con precisión, en los 4 "libros de los Académicos": T II, 2,4. El Hortensio, enamoró de la filosofía a S. Agustín: Conf., III, 4,1. Por su parte, Cicerón, fomentará su práctica y la de la Retórica: "De acuerdo: la práctica retórica antes de mediodía, y la filosofía a esta misma hora"(al atardecer):T II, 27,67.

\subsection{La virtud como fuente de felicidad y medicina de la gloria verdadera}

Con Bruto, dice Cicerón: "yo he llegado a tener plena conciencia de que sientes predilección por la tesis de que la virtud es en sí misma autosuficiente para una vida feliz": T V,1,1."En efecto, dado que ése fue el motivo que impulsó a quienes se dedicaron por primer vez al estudio de la filosofía a dar de lado a todo y entregarse en cuerpo y alma (totos) a la búsqueda de la condición de vida mejor, no cabe ninguna duda de que, por la esperanza de alcanzar una vida feliz, ellos pusieron en ese empeño tanto cuidado y esfuerzo": T V,1,2.

Sócrates bajó "la filosofía del cielo, la colocó en las ciudades, la introdujo también en las casas y la obligó a ocuparse de la vida y de las costumbres, del bien y del mal”: T V, 4,10. Y: “del mismo modo que si se admite que el bien moral es el sumo bien, de ello se sigue que la vida feliz se logra con la virtud, así también, si la vida feliz consiste en la virtud, no hay ningún bien excepto la virtud": $\mathrm{T}$ V,8,21. Y: "para la virtud, no hay teatro más importante que la conciencia": T II, 26,64.

Entonces, la filosofía es el estudio de la realidad sin "buscar nada para sí". Por eso, "en la vida la contemplación y el conocimiento de la realidad 
son actividades que superan con mucho a todas las demás": T V, 3,9. Epicuro une vivir de modo honesto, sabio y justo con el placer, y, para Cicerón: “en esta discusión, lo que nosotros deseamos sostener es que todos los buenos son siempre felices". A los "adornados de todas las virtudes unas veces los llamamos sabios y otras buenos": T V, 10,28. Así: "permanezcamos fieles a nuestro principio de que el hombre sabio es el más feliz": T V,11,34.

En el Gorgias, de Platón, Sócrates dice: “'Sí, eso es lo que pienso: que los buenos son felices y los malos infelices"':T V,12,35. Pues, la templanza modera los deseos y la valentía libra del miedo que impide "vivir feliz". El sabio se halla siempre en esta situación, "luego siempre es feliz". Esa "vida feliz se consigue con la virtud": T V,16,48. Y, lo que "queremos es que la virtud sea siempre libre, siempre invicta": T V,18,52. Pues: "la virtud es suficiente para vivir con fortaleza y suficiente también, por ello, para vivir felices": T V,18,53.

"Ahora bien, dado que es evidente que la vida feliz es el resultado de alegrías perpetuas y plenas, la consecuencia es que ella es el resultado del bien moral": T V, 23,67. El sabio levanta su mente a lo divino, y mira con gran paz las cosas de la tierra. Entonces: "Una vez examinadas las cuestiones de esta naturaleza, se llega a la conclusión fundamental que constituye el objeto de esta discusión, a saber, que la virtud se basta a sí misma para conseguir la felicidad": T V, 25,71.

Luego, se recuerda a Demóstenes que, algo vanidoso, no se cuestionó a sí mismo. “¡Pero qué gran orador! Es evidente que él enseñó a hablar a los otros, pero hablaba muy poco consigo mismo. Hay que comprender, pues, que no hay que buscar la gloria vulgar ni temer la vida oscura: "Yo llegué a Atenas, dice Demócrito, y nadie me conoció’ ¡Qué ejemplo de firmeza y dignidad da el hombre que se gloría de que se ha alejado de la gloria!": T V,36,103-4.

\section{Conclusión: Por favor: ¡No os olvidéis de vivir ni de haceros algo mejores!}

Al fin, para los antiguos y los modernos, como ha enseñado P. Hadot: "la filosofía es ante todo una manera de vivir", un modo de cambiar la vida, una terapéutica para superar nuestro yo "parcial y pasional" e integrarnos en la koinonia de la fraternidad humana, y, vivir con los otros, con un yo libre y racional, abierto al mundo, pues la filosofía no es "la construcción de un sistema" sino una "forma de vida", insiste J. Carlier ${ }^{20}$. Vivir bien es la

${ }^{20}$ P. Hadot, La filosofía como forma de vida. Conversaciones con Jeannie Carlier y Arnold I. Davidson, Barcelona 2009, 17. En adelante H. 
primera y definitiva filosofía. Montaigne dice a quien cree que ha perdido su día: “Cómo!, ¿no has vivido? Ésta es no sólo la fundamental, sino la más ilustre de tus ocupaciones": H 188-9.

En efecto, Hadot, al preguntarse por su auténtico yo, se encuentra con un "sentimiento oceánico" bien descrito por R. Rolland, que le sitúa en el mundo, más allá de él, y supera lo intrascendente: H 25. Es una mutua pertenencia del yo y el universo pero con una impresión de "inmersión, de dilatación del yo en Otro al que el yo no es extraño, ya que es una parte de él": H 29. Hadot esta experiencia la encuentra en Rolland, y, luego, en otros muchos autores: en el Journal de J. Green, en el Koestler de El cero y el infinito, en el Dostoievski de Los Hermanos Karamazov, y quizá en el Rousseau de Las ensoñaciones de un paseante solitario.

Todas esas experiencias, de Hadot, le llevan a darse cuenta que, como dice Bergson: "La filosofía no es una construcción de sistema, sino la resolución tomada una vez de mirar ingenuamente en sí y en torno a sí": H 301. También Hadot recuerda que P. Rabbow había subrayado la presencia de "ejercicios espirituales" en el mundo antiguo como la meditación, el diálogo, la confesión, el régimen alimenticio o la escucha de un maestro que induce a "progresar espiritualmente" y "transformarse interiormente": H 67. Los estudios de la esposa de Hadot sobre Séneca, también le ayudaron en este camino. Y, con estos temas como tarea investigadora, según ya expusimos, y con el apoyo de M. de Foucault, Hadot es elegido para el Collège de France en 1982: H 73.

Así, pues, la filosofía en el mundo Antiguo es esencialmente diálogo, "una relación viva entre personas" que: "Intenta formar, más que informar”, según la feliz fórmula de V. Goldschmidt. Pero, el paso del tiempo hizo ese saber abstracto, y: "Se ha perdido el aspecto personal y comunitario de la filosofía": H 94. Así, se pierde su rastro y su verdadero sentido, y se afirma alegremente que: "Aristóteles es incoherente" o que:"san Agustín compone mal": H 99.

Con este método es imposible entender la filosofía Antigua o las " $\mathrm{Me}$ ditaciones de Descartes, que son ejercicios espirituales que tienen en cuenta el tiempo que necesitará el lector para llegar a cambiar su mentalidad y transformar su manera de ver; los Exercices de Shaftesbury, inspirados por Marco Aurelio y Epicteto; los aforismos de Schopenhauer, de Nietzsche o el Tractatus de Wittgenstein": H 100. Pero, el discurso filosófico no es una mercadería de la elocuencia sino "un medio de superarse a sí mismo y de acceder al plan de la razón universal y de la apertura a los otros". Pues como dice, de modo admirable, Kant: sólo hay una tristeza y es la de no ser mejores... 
No obstante, aunque es difícil ir "a contra corriente de la moda actual", es lícito pedir al investigador y al servidor público la superación del subjetivismo que trastoca el bien común si no sabe "elevarse a una perspectiva universal". Para Hadot: "El desprendimiento de sí es una actitud moral que se le debería exigir tanto al político como al sabio": H 109.

Por otra parte, el investigador debe respetar los textos y procurar su actualización. Así, en el: Noli foras ire, in te ipsum redi, in interiore homine habitat veritas, hay una actualización, del hombre interior de san Pablo, por Agustín, "para afirmar que la Verdad se encuentra en la conversión del yo hacia sí mismo" y a Dios. Husserl pide al hombre que no se pierda en el mundo: H 117-8.

Según Plotino, la filosofía prepara la mística. Y, cuando el yo se hace "interior a sí mismo, a los otros y al Espíritu", hay cierta "experiencia mística” del Uno y del Bien, mientras que La mística salvaje (M. Hulin) es artificial y falsa: H 124. También en la vida ordinaria hay un cierto valor místico y un "escalofrío sagrado", como ha explicado muy bien Hugo de Hofmannsthal; y como lo dice Séneca: "El hombre es para el hombre algo sagrado": H 131. En ese caso, no venimos a la vida a perderlo todo sino a recibirlo todo. Es un: "Acoge todas las cosas" frente al consejo de Plotino: "Quita todas las cosas": H 130-1.

Plotino habla de un cierto yo que se pierde, de expansión de sí mismo y "de una intensificación del yo. Sería el aspecto de la transformación de sí": H 133. Es una pérdida y una ganancia que lleva a un orden superior: "el yo sale de sus límites y se dilata en el infinito". Así, el yo, para Hadot sería: el cuerpo y lo sensible, el alma y la conciencia, una conciencia embebida del Espíritu o Intelecto que da "una especie de lucidez espiritual e intuitiva sin discurso y sin reflexión”: H 134. Para P. Claudel es: "Alguien que sea en mí más yo mismo que yo". Dios, "intimior intimo meo" de Agustín que "ya está en el origen de mi yo". Plotino habla de la unión entre el yo y el Uno, Aristóteles de algo "divino y, sin embargo, es nuestro verdadero yo", M. Aurelio del daimon, "una divinidad interior": H 136. Este cambio del yo se da también en otras filosofías como en la china.

Entonces, Hadot “definiría el ejercicio espiritual como una práctica voluntaria, personal, destinada a operar una transformación en el individuo, una transformación de sí”: H 137-8. Esta expresión, “ejercicios espirituales", no está muy bien vista. Discutida por S. Laughier y aceptada por Brisson y Onfray. En Rabbow, los "ejercicios espirituales" de Ignacio se enraizarían en los monjes herederos del mundo antiguo y su primer sentido no sería religioso. Para Hadot, hay pocas alternativas a esta expresión aunque sea problemática. R. Ruyer habló de "prácticas", Foucault de "prácti- 
cas de sî", y Hadot repite a G. Friedmann. Cierto que, esa expresión, de por sí, no basta, pero: "la filosofía antigua: es ejercicio espiritual porque es un modo de vida, una forma de vida, una elección de vida": H 146. Ésta nos sitúa en el centro del "acontecimiento inmenso del universo" y "en el misterio insondable de la existencia" que va del yo empírico al trascendental: H 150.

Esta práctica permite soportar los golpes de la fortuna como el exilio, la enfermedad, la pobreza y otras adversidades e incluso la muerte para separarnos de nuestro egoísmo y de nosotros mismos. Como dice el Fedón: "Filosofar es ejercitarse en morir": H 138. Eso supone un discurso interior y tomar postura. W. Jaeger ve, con Goldschmidt, la filosofía como Paideia o "formación" y Epicteto dice del discípulo que ha progresado: "está 'formado"” (H 142), y, vivirá bien: "pues, la práctica de la vida cotidiana de Sócrates es su verdadera filosofía": H 156.

En Kant y en Nietzsche se puede hablar de la mezcla de "una energía estoica y una alegría de vivir epicúrea". Somos libres e independientes y vivimos el día a día inspirados "en el epicureismo, en el estoicismo, en el platonismo o en cualquier otro modelo de vida": H 157. Estamos ante una "elección de vida" que necesita también de "la reflexión teórica". Pues, al someternos a la razón nos alejamos del egoísmo y nos preocupamos por los demás.

Entonces, nos preocupa "el bien común”, como a M. Aurelio, o, a Epicuro, "la amistad porque es un placer puro". Pero nadie será feliz, dice Séneca, si sólo mira por sí mismo. Uno, debe cambiarse a sí mismo, sin complacerse a sí mismo, como dice M. Aurelio. Y: "esta transformación de sí mismo consiste precisamente en estar atentos a los demás": H 166. También Hadot se ha esforzado por "llevar una vida filosófica" o sea una vida "consciente, coherente y racional" aunque no siempre lo ha conseguido. Ahora bien, según Friedmann, hay que "emprender el vuelo cada día" y "tomar conciencia del misterio de la existencia": H 171.

En fin, en esta hora de su vida ${ }^{21}$, Hadot prefiere "cada vez más la experiencia al discurso", pues según un proverbio chino, citado por S. Leys: "Todo lo que puede enunciarse está desprovisto de importancia": H 171.Y, sobre lo que es más "útil al hombre en tanto que hombre", "hay una primacía de la razón práctica, explícita en Kant, implícita en la idea antigua de la filosofía”: H 172. Más aún: "Me permitiré citar aquí a Kant: ¿Cuándo

${ }^{21}$ Aquí la referencia es la entrevista de la nota 16, pues Hadot murió en la noche del 24-25-4-2010. Cf., M. Chase, Remembering Pierre Hadot, Part I \& II, Harvard University Press Blog, 28-29-4-2010. 
empezarás a vivir virtuosamente?, decía Platón a un anciano que le contaba que escuchaba lecciones sobre la virtud"": H 176. Hay que pasar, de una vez, de la teoría a la práctica. De lo contrario, la filosofía sería como una ópera en la que "la gente canta: 'Caminemos, caminemos' o 'huyamos, huyamos' y no se mueven”. Para Hadot, es vicio de filósofo quedarse en "el discurso bien hecho, porque es más fácil hablar que hacer": H 176.

En la Antigüedad, "la figura del sabio" era "el filósofo ideal". Según Lucrecio, su primera característica es "su amor hacia los hombres", la segunda superar las barreras del universo y llegar al "Todo inmenso", y la tercera "la paz de su alma", en la libertad inexpugnable de su ciudadela interior, frente a todo temor inútil: $\mathrm{H}$ 177. El modelo ideal no existe, ni el verdadero cristiano ideal ni se debe declarar a nadie sabio o santo, pues: "Ambos son normas": H 178.

Para Hadot, la paz y la libertad interior, la conciencia cósmica, y no dar la espalda a la miseria humana ni "a la cloaca de los hombres" (Friedmann), siguen siendo ideales fundamentales del sabio: H 179. Por tanto, hoy la paz del alma se ha de conquistar entre las tormentas de nuestro mundo (S. Weil), aunque, como la sabiduría, nunca se consiga del todo. En todo caso, el ejemplo a seguir será siempre Sócrates que no escribió ni enseñó, en la escuela, pero "se dirigía a aquellos que se encontraba por la calle y que tuvo dificultades con la opinión pública y el poder” (M. Ponty): H 183.

Montaigne amaba también la sencillez de Sócrates, su confianza en la naturaleza humana, que daba coraje para vivir y morir a la gente humilde, sin grandes discursos filosóficos, porque "vive plena y simplemente una vida humana": H 185. Es más, Montaigne considera el hecho mismo de vivir como la más ilustre de las ocupaciones: H 188-9.

Jankélévich, que sigue a Bergson, en el tema de la mirada ingenua y el amor puro, captó muy bien el gran misterio de ese amor que puede expresarse así: “¿cómo pueden los amantes ser egoístas e interesados, mientras que su amor los trasciende y es puro y desinteresado?": H 192. M. Ponty cree que "la filosofía consiste en volver a aprender a ver el mundo": H 197.

La idea de que "la filosofía también era un ejercicio espiritual" le vino a Hadot de los juegos de lenguaje de Wittgenstein, pues éste utilizaba "la expresión "forma de vida" para "comprender la filosofía". Esta forma de vida no puede quedarse en mero dandismo, como puede ocurrir con las "prácticas de sí" de Foucault, sino que debe llevar a "la mejor parte del yo", a la conciencia "de la pertenencia al Todo cósmico" y a la "comunidad humana”, y, así, al yo auténtico y la razón universal que es la fuente de la verdadera alegría frente al mero placer. Así, llegamos al valor absoluto y a la máxima moral kantiana de valor universal. 
Entonces: "El Valor absoluto se sitúa en el nivel de una elevación del yo, del yo que se hace así capaz de ponerse en el lugar de los demás, de purificar su intención, es decir, de actuar de manera desinteresada, por amor o por deber": H 207. Sólo así se reconstruye la ciudadela interior del ser humano preocupado por el bien común de todos y de cada persona con una intención pura siempre sujeta a la razón más sublime, y que hemos expuesto con M. Aurelio.

Por lo demás, Hadot precisa que no fue el cristianismo el que proclamó la huida del cuerpo sino el neoplatonismo; ni el estoicismo es una filosofía insensible al dolor humano, sino su vulgarización, pues como dijo Séneca: "Ninguna escuela tiene más amor hacia los hombres ni está más atenta al bien de todos": H 228. Por lo demás, aunque la filosofía antigua sea un modo de vida no quiere decir que todas sus propuestas sean hoy aceptables ni aprovechables. Lo que sí es cierto es que la riqueza, el placer, el poder y los honores siempre han sido y son aún hoy objeto del deseo humano, y hay que evitar que nos arrastren, arrollen, anublen, tuerzan o anulen la razón.

Finalmente, "es muy curioso, para Hadot, que el tema de la muerte y la meditación de la muerte ayude tanto a vivir mejor". H 239. Pues, mirar menos al pasado y no huir hacia el futuro nos enseña el valor infinito del presente y nos ayuda a "tomar conciencia de la seriedad de cada momento de la vida". El valor del momento presente reconocido, por los estoicos y los epicúreos, muestra que "podemos dar un valor en cierto sentido absoluto a cada instante de la vida, por banal que sea, por humilde que esa": H 240. Eso evoca la anécdota de Péguy sobre san Luis Gonzaga y la muerte.

$\mathrm{O}$, como lo dice Goethe, la felicidad sólo se encuentra en el momento presente sin mirar atrás ni adelante. Para él, la clave de la vida y del arte antiguo "era saber vivir en el presente; conocer como decía "la salud del momento": H241. La clave de la vida es alegrarse del presente y confiar a Dios el futuro, y, como el pasado nos apena y el futuro nos inquieta, hay que disfrutar "a cada instante el placer de existir" como recomienda Rousseau. Los verdaderos amantes siempre viven el presente porque "tan sólo el presente es la felicidad". Pero, ésta no es un simple momento feliz de placer sino que "consiste en saber reconocer el valor infinito de cada momento": H 244.

Así, no es bueno huir hacia el pasado ni refugiarse en el futuro, pues es preciso saber que: "ahí estoy, aquí, vivo, y esto basta", es decir, debemos tomar conciencia del valor de la vida y "gozar del placer de existir", "por el gozo de hacer el bien", como decía Montaigne, a quien tenía la impresión de no haber hecho nada importante: $\mathrm{H}$ 245. En definitiva, es preciso "liberarse de la fascinación del futuro y de la rutina cotidiana": H 245. 
Por lo demás, es preciso también mirar el mundo desde lo alto, recorrer el espacio del mundo y acompañar a los astros, para situar al hombre ante el mundo y que tome conciencia de lo que es, tanto de su grandeza como de su debilidad, de su fragilidad y del "vuelo del alma hacia el infinito", como dice Lucrecio de Epicuro. Así, podrá recuperar "una perspectiva universal" que le permita superar "su punto de vista egoísta" y llegar "a la imparcialidad" en todo, en la historia humana y en la vida: H 247. Este tema lo encontramos en Pascal, Voltaire, Baudelaire o en Goethe.

Estamos ante un ejercicio espiritual que cambia la cosmología y la mitología, y libra el propio yo a una perspectiva universal que nos sumerge no sólo en el "Todo del Universo" sino también en el "Todo de la comunidad humana", que exige: "Salir de una visión unilateral de las cosas, ponerse en el lugar de los demás": H 248. Es una ilusión óptica pensar que cada persona es una realidad separada e independiente de todo. Pues, según un texto atribuido a Einstein: "Un Ser Humano no es más que una parte, limitada en el tiempo y en el espacio, del Todo que llamamos 'El Universo'". Y, él mismo dice: "para conocer el auténtico valor de un hombre hay que preguntarse en qué grado y con que fin se ha liberado de su yo": H 249.

En Séneca (CL 95,33) se encuentra el famoso texto: "el hombre, algo sagrado para el hombre", que rechaza la muerte de hombres en el circo, como castigo de sus crímenes. Epicteto hablará de los esclavos como de los "hijos de Dios". El estoicismo asegura "la igualdad absoluta entre todos los ciudadanos" de todas las clases sociales, de hombres y mujeres, de posesión de tierras, y de pago de deudas, reformas agrarias y de liberación de esclavos: H 251. M. Aurelio buscaba esa igualdad: "todos tendrían libertad de palabra" y "se respetaría la libertad de los sujetos", era escrupuloso en "hacer justicia", "facilitar la liberación de los esclavos", no gravar "con un impuesto demasiado grande" y proteger a las personas en peligro como en el caso de "unos niños funámbulos": H 252.

Así, M. Aurelio nos incita a respetar a los otros, ser imparciales y desinteresados, hacer el bien siempre, no atarse al propio egoísmo y aceptar los consejos de los demás. Estas propuestas conservan "su valor aún hoy". Sócrates se preocupaba por todos, especialmente en lo espiritual. Los Gracos y M. Escévola "se preocuparon por el bienestar de los hombres y muy especialmente de los pobres": H 253. Hoy en día, la práctica filosófica que permita aminorar el sufrimiento humano, la enfermedad y la miseria, es la única digna de ser impulsada, y, esa es la política basada en la ética, la única digna de ese nombre. Para Vaclav Havel: "al fin y al cabo la única política a la que estoy dispuesto a dedicarme, es sencillamente el servicio al prójimo, el servicio a la comunidad". 
Así, la filosofía es como volver a mirarlo todo y vivirlo con esa ingenuidad maravillosa que permite ver el "esplendor del mundo, que habitualmente se nos escapa": H 254. Entonces nos quedaríamos estupefactos ante tanta novedad (CL 64,6), ante "el milagro inaudito de la existencia del mundo". J. Wahl traduce al poeta Th. Traherne, que afirma: "Todo lo que veía me parecía un milagro".Y, el Fausto de Goethe: "En todo percibo la eterna belleza": H 254.

Para Rilke: "Estar aquí abajo es un esplendor". "Wittgenstein decía que su experiencia por excelencia era el maravillarse ante la existencia del mundo" H 255. Pero, el esplendor de la vida no debe ocultar su dolor y horror. Para Aristóteles: "En todas las obras de la Naturaleza, decía, hay algo maravilloso": H 255. Pero, para el que sufre, la vida no es maravillosa. Observa Schopenhauer, que una cosa es idealizar la miseria y otra, muy distinta, sufrirla. La vida filosófica consiste, precisamente, en el valor de asumir esa situación. Para Montaigne, algunos seres humanos muy 'ordinarios' y 'simples' "tienen este coraje y acceden así, por otro lado, a la vida filosófica": H 255. Y, a pesar de su dolor, ven el "mundo como algo espléndido". R. Luxemburgo, en sus cartas desde la prisión, manifiesta eso mismo y son "un himno a la belleza del mundo". Rosa se pregunta: "Ante un cielo así, ¿cómo se podría ser malo o mezquino?”: H 256. Y, un héroe prisionero, de El primer círculo de Soljenitsyn, dice que: "el puro gozo de existir me hace temblar": H 256.

Epicuro nos dice: "Ante este espectáculo, una especie de placer divino y un estremecimiento de espanto me sobrecogen": H 256. Por el enigma de la vida, dice Goethe, lo mejor del hombre experimenta un "estremecimiento sagrado". Los modernos han descrito muy bien este esplendor y temor, que cuando "nos sobrecoge, no hay que intentar sustraerse a él, porque nos da el coraje para afrontar el indecible misterio de la existencia": H 256.

S. Agustín describe esta experiencia, y asegura que "me enardezco y me horrorizo", "inhorresco et inardesco"(Confs. IX, 4,9). Él, lo refiere directamente al Dios misericordioso y la experiencia de lo santo que debe infundirnos el entusiasmo necesario para vivir bien la vida y a hacernos mucho mejores. Pues, hoy, según Hugo de Hofmannsthal: "La mayoría de la gente no vive en la vida, sino en un simulacro, en una especie de álgebra donde nada existe y donde todo solamente significa. Querría experimentar profundamente el ser de toda cosa”...: H 261.

O como dice Rilke: "Debemos aceptar nuestra existencia en toda la medida en que corresponda: todo, aun lo inaudito, debe ser posible en ella. Esto es en el fondo la única valentía que se nos exige: ser valiente para lo más extraño, asombroso e inexplicable que nos puede ocurrir (...) Pero el miedo a 
lo inexplicable no sólo ha hecho más pobre la existencia del individuo, sino que también las relaciones de persona a persona están limitadas por él, como si se las hubiera sacado del cauce de las posibilidades infinitas a una orilla baldía, donde nada tiene lugar": H 262.

Kant, por su parte, describió certeramente esa experiencia en su famoso pasaje: "Dos cosas me llenan el ánimo de admiración y respeto, siempre nuevos y crecientes, cuánto con más frecuencia y aplicación se ocupa de ellas la reflexión: el cielo estrellado sobre mí y la ley moral en mí (...) y las enlazo inmediatamente con la conciencia de mi existencia”: H 259. 